\title{
Pesticide and veterinary drug residues in honey - validation of methods and a survey of organic and conventional honeys from Slovenia
}

\author{
Helena Baša Česnik*a ${ }^{\mathrm{a}}$, Veronika Kmecl ${ }^{\mathrm{a}}$, Špela Velikonja Bolta ${ }^{\mathrm{a}}$ \\ ${ }^{a}$ Agricultural Institute of Slovenia, Central Laboratories, Hacquetova ulica 17, SI-1000 \\ Ljubljana, Slovenia
}

*Corresponding author

Helena Baša Česnik

Agricultural Institute of Slovenia, Central Laboratories, Hacquetova ulica 17, SI-1000

Ljubljana, Slovenia

+38612805249

helena.basa@kis.si

Biographical notes:

Helena Baša Česnik has worked as an analyst in the field of pesticide residues for 18 years. She has also evaluated plant protection products and active substances dossiers in the field of residues, for the purpose of authorisation in Slovenia and European Union, for 17 years.

Veronika Kmecl has worked as an analyst in the field of honey analysis for 21 years. She has also evaluated plant protection products dossiers in the field of physicochemical properties and analytical methods for the purpose of authorisation in Slovenia and European Union, for 5 years.

Špela Velikonja Bolta has worked as an analyst in the field of pesticide residues for 16 years. She has also evaluated plant protection products and active substances dossiers in the field of physicochemical properties and analytical methods for the purpose of authorisation in Slovenia and European Union, for 7 years. 


\title{
Pesticide and veterinary drug residues in honey - validation of methods and a survey of organic and conventional honeys from Slovenia
}

\author{
Four analytical methods for the determination of veterinary drug residues, as well \\ as environmental pesticide residues in honey, were introduced and validated: a) \\ the GC/MS method for the analysis of amitraz and all metabolites containing the \\ 2,4-dimethylaniline moiety, b) the GC/MS method for the analysis of thymol, \\ chlorfenvinphos and coumaphos, c) the GC/MS method for the analysis of 75 \\ active substances and d) the LC-MS/MS method for the analysis of 60 active \\ substances. Between GC/MS (point c) and LC-MS/MS method (point d) there \\ was no overlap among active substances, meaning that with both methods 135 \\ active substances originating from the environment in total were introduced and \\ validated. The first method included hydrolysis of amitraz and its metabolites \\ containing the 2,4-dimethylaniline moiety to 2,4-dimethylanilin and extraction of \\ 2,4-dimethylanilin to n-hexane. The other three methods had the same extraction \\ procedure with a mixture of solvents: acetone, dichloromethane and petroleum \\ ether. All 4 methods were tested in practice. 60 samples were analysed: 22 from \\ organic and 38 from conventional production. Overall, residues are mainly higher \\ than reported in literature but do not exceed MRLs. Calculation of the risk \\ assessment confirmed that the analysed samples are of no cause for concern for \\ consumers.
}

Keywords: honey; organic honey; conventional honey; acaricides; pesticide residues; GC/MS; LC-MS/MS

\section{Introduction}

Nowadays, dietitians recommend honey not only because of its nutritional properties, but also as a natural sweetener, which can be used by diabetics as well. Consumers demand safe and high quality products, therefore analysis of honey on pesticide residues is required. 
Calatayud-Vernich et al. (2016) found in honeybees, pesticide residues from two sources: the ones originating from the environment and the ones originating from veterinary drug use. This means that both types of pesticides can be found in honey as well.

Veterinary practices in conventional production expose honeybees to acaricides such as amitraz and coumaphos. These substances control Varroa destructor and Varroa jacobsoni, mites that attack honeybees, described by Anderson and Trueman (2000). In the case of organic honey production, only thymol, menthol, eucalyptol, camphor, formic acid, lactic acid, acetic acid and oxalic acid are used to supress varroa as laid down in Regulation (EC) 889/2008.

In both types of production (conventional and ecological) beekeepers cannot avoid possible contamination from the environment. Honeybees fly $4.8 \mathrm{~km}$ from their apiary (Eckert, 1933) during which they can pick contaminants from plants, soil and air (Zhou, 2018). Plant protection products (PPPs) do not only reach treated plants, but also drift to soil and air. In the air, aerosols are formed, containing PPP residues which can travel and deposit in surroundings where they can come into contact with bees.

In the European Union, maximum residue limits (MRLs) are set for both types of contaminants. In Regulation (EC) 396/2005, MRLs are set for pesticides from the environment. In Regulation (EC) 37/2010, MRLs are set for pharmacologically active substances.

Chiesa et al. (2016) already measured the active substances: aldrin, boscalid, captan, chlorpyrifos, coumaphos, diazinon, dieldrin, endrin, heptachlor, iprodione, methoxychlor, mevinphos, p,p'-DDD, p,p'-DDE, p,p'-DDT, quinoxyfen, and trifloxystrobin in organic honey samples from Italy. On the contrary, Panseri et al. (2014) found no pesticide residues in Italian honey from organic production. The 
exceptions were Italian honey samples in the vicinity of apple orchards or industrialised areas, and from the market, where boscalid, captan, chlorpyrifos, dieldrin, heptachlor, iprodione, methoxychlor, p,p'-DDE, p,p'-DDD, p,p'-DDT, quinoxyfen and trifloxystrobin were found. In Polish honey, Bargańska et al. (2013) found the active substances azinphos-ethyl, azinphos-methyl, bifenthrin, carfentrazone-ethyl, chloridazon, coumaphos, diazinon, dimethoate, dimoxystrobin, fenpyroximate, haloxyfop-R-methyl, heptenophos, imidacloprid, indoxacarb, methidathion, methiocarb, methomyl, omethoate, oxamyl, oxydemeton-methyl, pirimicarb, profenofos, pyrazophos, qualiafos, spinosad, temephos, thiamethoxam and triazophos. Furthermore, Kujawski and Namieśnik (2011) found clothianidin, carfentrazone ethyl, fluroxypyrmeptyl, methidathion, imazalil and chlorpyrifos in Polish honey samples. Numerous active substances found in honey from Italy and Poland were included in our analytical methods.

The determination of environmental pesticide residues and veterinary drug residues in honey is nowadays performed with very sensitive equipment, like gas chromatography coupled with tandem mass spectrometry (GC/MS/MS) (Shendy et al. 2016), or liquid chromatography coupled with tandem mass spectrometry (LC-MS/MS) (Jin et al. 2017; Juan-Borrás et al. 2016; Tette et al. 2016). Extraction for GC/MS/MS and LC-MS/MS determination is usually performed with acetonitrile, with the modified QuEChERs method (Jin et al. 2017; Juan-Borrás et al. 2016; Shendy et al. 2016; Tette et al. 2016). On the contrary, some laboratories still use extraction with large volumes of organic solvents like ethyl acetate and/or methanol (Panseri et al. 2014; Rodríguez López et al. 2014), dispersive liquid-liquid microextraction (DLLME) (Farajzadeh et al. 2014; Zacharis et al. 2012) or solid phase extraction (SPE) combined with DLLME (Shamsipur et al. 2016,) followed by determination with a gas chromatograph coupled 
with a mass spectrometer (GC/MS) (Shamsipur et al. 2016; Wang et al. 2010; Zacharis et al. 2012), electron capture detector (ECD) (Malhat et al. 2015; Zacharis et al. 2012) or nitrogen phosphorus detector (NPD) (Farajzadeh et al. 2014; Rodríguez López et al. 2014).

Each solvent used for liquid-liquid extraction has some advanatages and some disadvantages. The weakness of solvent ethyl acetate are high co-extraction of interferences from matrix (Andersson and Pålsheden1991) and its non miscibility with water. The strength of ethyl acetate is that it gives good recoveries for numerous active substances with different properties (from polar like methamidophos to non-polar like chlorpyriphos) as observed by Vidal et al. (2006). To even improve its extraction abilities to polar active compounds, methanol can be added (Rodríguez López et al. 2014). The weakness of solvent acetonitrile is that in comparison with ethyl acetate and acetone it is less volatile, meaning that it takes longer to evaporate in injector of GC. Its strength is that in comparison to acetone and ethyl acetate it does not co-extract lipophilic materials such as wax, fat and lipophilic pigments (Anastassiades et al. 2003).

The drawback of liquid-liquid extraction is that large volumes of organic solvents are used. On the contrary in DLLME active substances are extracted with low volumes of an extraction solvent and a disperser solvent, meaning that the methods are environment friendly and low cost (Rezaee et al. 2006). The main weakness of DLLME method is, that it is suitable for trace analyses in range up to $0.05 \mathrm{mg} \mathrm{kg}^{-1}$ (Zacharis et al. 2012). DLLME in combination with SPE provides high preconcentration factors and is suitable for ultra-trace analyses up to $0.01 \mathrm{mgkg}^{-1}$ (Shamsipur et al. 2016). Since numerous MRLs for active substances in honey are $0.05 \mathrm{mg} / \mathrm{kg}$, DLLME method is not suitable for measurement of possible MRL exceedances for numerous active substances. 
In our laboratory, we introduced the single residue method for amitraz and all its metabolites containing the 2,4-dimethylaniline moiety, with GC/MS determination. For environmental pesticide residues, one extraction method was introduced for multiresidual GC/MS and LC-MS/MS determination. We have chosen liquid-liquid extraction with acetone, with purpose to introduce analytical method for measuring conformity of pesticide residues with valid MRLs. The strength of acetone is that it is more volatile than acetonitrile and it is therefore easier to concentrate it and remove it than acetonitrile. Besides, at extraction of materials containing high amount of sugar with acetone, no double layered extract is obtained like with acetonitrile (Luke et al. 1975). To acetone, dichloromethane and petroleum ether were added as extraction solvents, to achieve the extraction of very polar (for instance, thiamethoxam and trichlorfon) to non-polar (for instance, chlorpyrifos, cyhalothrin-lambda) pesticides at the same time. The same extraction procedure was tested and found to be suitable for the extraction of veterinary drug residues: thymol and coumaphos, and residues of acaricide chlorfenvinphos where determination was performed with GC/MS.

Once the methods were introduced, 60 samples of honey originating from organic and conventional production in Slovenia were analysed with all the methods presented in this paper and compared with data from literature. A risk assessment was performed for active substances found in honey samples.

\section{Materials and methods}

\section{Sample collection}

30 honey samples were collected in June and July 2017 and 30 in June and July 2018, 
from Slovenian beekeepers from all 12 statistical regions in Slovenia. Sampling distribution is presented in Table 1.38 samples originated from conventional production, meaning that beekeepers had the opportunity to use all registered veterinary products to supress varroa and 22 samples from organic production, meaning that beekeepers had the opportunity to use only thymol, formic acid and oxalic acid to supress varroa. Slovenia is one of the smallest producers of honey in the European Union, therefore in our survey we had a limited number of samples. Especially limited is the set of organic samples, since beekeepers in Slovenia rarely use only products approved in this type of production.

\section{Chemicals and reagents}

The certified standards were either from Sigma-Aldrich (Steinheim, Germany), or from Dr. Ehrenstorfer (Augsburg, Germany). Acetone p.a., acetone HPLC-grade, dichloromethane p.a., petroleum ether p.a., ethyl acetate p.a., ethyl acetate HPLC-grade, cyclohexane p.a., cyclohexane HPLC-grade, methanol p.a., methanol HPLC-MS-grade, n-hexane HPLC-grade were from J.T.Baker (Deventer, Netherlands). All other chemicals used were from Sigma-Aldrich (Steinheim, Germany). The water used was MilliQ deionised water.

For the preparation of the standard solutions for GC/MS, solvents of HPLCgrade were used. For the preparation of the standard solutions for LC-MS/MS, solvents of HPLC-MS grade were used. 
Determination of amitraz and all metabolites containing the 2,4-dimethylaniline moiety

With this method, the samples were analysed immediately after arrival at the laboratory.

\section{Preparation of solutions}

Stock solutions of amitraz and 2,4-dimethylaniline (2,4 DMA) in acetone HPLC-grade were prepared with a concentration of $1000 \mu \mathrm{g} \mathrm{mL} \mathrm{m}^{-1}$. From stock solutions, working solutions of amitraz and 2,4 DMA were prepared at the concentrations $100 \mu \mathrm{g} \mathrm{mL}^{-1}$ and $10 \mu \mathrm{g} \mathrm{mL} \mathrm{L}^{-1}$ respectively. From the working solution of 2,4 DMA $\left(10 \mu \mathrm{g} \mathrm{mL} \mathrm{m}^{-1}\right)$, matrix match standards were prepared for calibration when samples were analysed, for linearity and LOQ determination. The working solution of amitraz $\left(10 \mu \mathrm{g} \mathrm{mL} \mathrm{L}^{-1}\right)$ was used for determining other validation parameters.

\section{Hydrolysis and extraction procedure}

To $10 \mathrm{~g}$ of honey, $40 \mathrm{~mL}$ of $2 \mathrm{~N} \mathrm{HCl}$ was added. The contents of the beaker were stirred for 1 hour. Afterwards, $2 \mathrm{M} \mathrm{NaOH}$ was added until the solution reached $\mathrm{pH} 11$. Then, 20 $\mathrm{mL}$ of $\mathrm{n}$-hexane was added and the mixture was transferred into the separatory funnel. The water phase was re-extracted once again. Organic phases were collected and nhexane was added until the final volume was $40 \mathrm{~mL} .1 .5 \mathrm{~mL}$ of extract was transferred into a tube. Afterwards, heptafluorobutyric anhydride (HFBA) was added. Derivatisation took place at room temperature for 5 minutes. Excess of HFBA was removed with $4 \mathrm{~mL}$ of $1 \mathrm{M} \mathrm{Na}_{2} \mathrm{CO}_{3}$ water solution. The organic phase was transferred to a vial for GC/MS determination. 
The samples were analysed using a gas chromatograph (Hewlett Packard 6890, Böblingen, Germany) and column, an DB-2255 MS (Agilent Technologies, 30 m, 0.25 $\mathrm{mm}$ i.d., $0.25 \mu \mathrm{m}$ film thickness) with a constant flow of helium at $1.2 \mathrm{~mL} \mathrm{~min}^{-1}$. The GC oven was programmed as follows: $50^{\circ} \mathrm{C}$ for $1 \mathrm{~min}$, from 50 to $220^{\circ} \mathrm{C}$ at $4^{\circ} \mathrm{C} \mathrm{min}{ }^{-1}$ and held at $220^{\circ} \mathrm{C}$ for $5 \mathrm{~min}$. For the determination of analytes, a mass spectrometer (Hewlett Packard 5973, Palo Alto, CA, USA) was used. The temperature of the ion source was $230^{\circ} \mathrm{C}$, the auxiliary temperature was $240^{\circ} \mathrm{C}$, and the quadrupole temperature was $150^{\circ} \mathrm{C}$. For qualitative determination, retention time and mass spectrum in a selective ion monitoring mode (SIM) were used. One target and 2 qualifier ions, presented in Table 2, were used for the active substance. Calibration was performed to matrix match standards.

\section{Determination of chlorfenvinphos, coumaphos and thymol}

With this method, the samples were analysed immediately after arrival at the laboratory.

\section{Preparation of solutions}

Stock solutions in a mixture of ethyl acetate and cyclohexane at a ratio of 1 to $1(\mathrm{v} / \mathrm{v})$ of the individual active substances were prepared with the concentrations $100 \mu \mathrm{g}$ pesticide $\mathrm{mL}^{-1}$. From 3 stock solutions, three mixed solutions, each containing all 3 active substances, were prepared: one with a concentration of $5 \mu \mathrm{g} \mathrm{mL} L^{-1}$ for all 3 active substances, the second wth a concentration of $5 \mu \mathrm{g} \mathrm{mL}{ }^{-1}$ for chlorfenvinphos, $4.5 \mu \mathrm{g}$ $\mathrm{mL}^{-1}$ for coumaphos and $35 \mu \mathrm{g} \mathrm{mL}^{-1}$ for thymol, and the third one at the limit of quantification (LOQ) of the active substances. From the first solution, diluted solutions 
were prepared for calibration when samples were analysed for LOQ determination. The second solution was used for the preparation of diluted solutions for linearity determination. The third solution was used for determining other validation parameters.

\section{Extraction procedure}

$20 \mathrm{~g}$ of honey and $15 \mathrm{ml}$ of MilliQ water was added to the beaker. The honey was dissolved in the water, then $40 \mathrm{ml}$ of acetone p.a. was added. The mixture was homogenised for 2 minutes with a mixer. Then, an $80 \mathrm{ml}$ mixture of petroleum ether p.a. and dichloromethane p.a. at a ratio 1:1 (v/v) was added and mixed for another 2 minutes with a mixer. This mixture was transferred into the separatory funnel, containing $3 \mathrm{~g}$ of $\mathrm{NaCl}$. The vessel was rinsed with an $80 \mathrm{ml}$ mixture of petroleum ether p.a. and dichloromethane p.a. at a ratio 1:1 (v/v). The solvent was added to the separatory funnel, which was shaken for 1 minute. The upper organic phase was filtered through $15 \mathrm{~g}$ anhydrous $\mathrm{Na}_{2} \mathrm{SO}_{4}$ in a $500 \mathrm{ml}$ Soxhlet flask. The lower water phase was re-extracted twice using the same procedure. Solvents in collected organic phases were evaporated to approximately $2 \mathrm{ml}$ on rotavapor and dried with nitrogen flow. To dry the eluate, $2 \mathrm{ml}$ of the mixture of ethyl acetate p.a. and cyclohexane p.a. at a ratio of 1:1 (v/v) was added in the case of a sample preparation. In the case of matrix match standards, $2 \mathrm{ml}$ of working solutions with proper concentrations were added.

\section{Determination with GC/MS}

The samples were analysed using a gas chromatograph (Agilent Technologies 7890A, Shanghai, China) equipped with a Gerstel MPS2 multipurpose sampler (Gerstel, Mülheim an der Ruhr, Germany) and column, an HP-5 MS (Agilent Technologies, 30 $\mathrm{m}, 0.25 \mathrm{~mm}$ i.d., $0.25 \mu \mathrm{m}$ film thickness) with a constant flow of helium at $1.2 \mathrm{~mL} \mathrm{~min}^{-}$ 
1. The GC oven was programmed as follows: $40^{\circ} \mathrm{C}$ for $1 \mathrm{~min}$, from 40 to $150^{\circ} \mathrm{C}$ at $20^{\circ} \mathrm{C}$ $\min ^{-1}$, from 150 to $200^{\circ} \mathrm{C}$ at $5^{\circ} \mathrm{C} \mathrm{min}^{-1}$, from 200 to $280^{\circ} \mathrm{C}$ at $10^{\circ} \mathrm{C} \mathrm{min}^{-1}$ then held at $280^{\circ} \mathrm{C}$ for $20 \mathrm{~min}$. For the determination of analytes, a mass spectrometer (Agilent Technologies 5975C, upgraded with a triple-axis detector, Palo Alto, CA, USA) was used. The temperature of the ion source was $230^{\circ} \mathrm{C}$, the auxiliary temperature was $280^{\circ} \mathrm{C}$ and the quadrupole temperature was $150^{\circ} \mathrm{C}$. For qualitative determination, retention time and mass spectrum in SIM were used. One target and 2-3 qualifier ions, presented in Table 2, were used for each active substance. The calibration was performed to matrix match standards.

\section{Multiresidual GC/MS method}

With this method, the samples were analysed within a maximum period of six months after arrival at the laboratory. During that time, they were stored at $-20^{\circ} \mathrm{C}$.

\section{Preparation of solutions}

Stock solutions in a mixture of ethyl acetate and cyclohexane at a ratio of 1 to $1(\mathrm{v} / \mathrm{v})$ of individual active substances were prepared with the concentrations $625 \mu \mathrm{g}$ pesticide $\mathrm{mL}^{-1}$. From 75 stock solutions, two mix solutions of all 75 active substances were prepared: one with a concentration of $5 \mu \mathrm{g} \mathrm{mL}^{-1}$ and the second one at LOQ of active substances. All solutions used to determine linearity, LOQs and perform calibration when samples were analysed were prepared from a mix solution of $5 \mu \mathrm{g} \mathrm{mL}{ }^{-1}$ with proper dilutions. For other validation parameters, a mixed solution with a concentration at LOQ was used. 


\section{Extraction procedure}

The extraction procedure is the same as for the determination of chlorfenvinphos, coumaphos and thymol.

\section{Determination with GC/MS}

The samples were analysed using a gas chromatograph (Agilent Technologies 7890A, Shanghai, China) equipped with a Gerstel MPS2 multipurpose sampler (Gerstel, Mülheim an der Ruhr, Germany) and column, an HP-5 MS UI (Agilent Technologies, $30 \mathrm{~m}, 0.25 \mathrm{~mm}$ i.d., $0.25 \mu \mathrm{m}$ film thickness) with a constant flow of helium at $1.2 \mathrm{~mL}$ $\min ^{-1}$. The GC oven was programmed as follows: $55^{\circ} \mathrm{C}$ for $2 \mathrm{~min}$, from 55 to $130^{\circ} \mathrm{C}$ at $25^{\circ} \mathrm{C} \mathrm{min}{ }^{-1}$, held at $130^{\circ} \mathrm{C}$ for $1 \mathrm{~min}$, from 130 to $180^{\circ} \mathrm{C}$ at $5^{\circ} \mathrm{C} \mathrm{min}^{-1}$, held at $180^{\circ} \mathrm{C}$ for $30 \mathrm{~min}$, from 180 to $230^{\circ} \mathrm{C}$ at $20^{\circ} \mathrm{C} \mathrm{min}^{-1}$, held at $230^{\circ} \mathrm{C}$ for $16 \mathrm{~min}$, from 230 to $250^{\circ} \mathrm{C}$ at $20^{\circ} \mathrm{C} \mathrm{min}{ }^{-1}$, held at $250^{\circ} \mathrm{C}$ for $13 \mathrm{~min}$, from 250 to $280^{\circ} \mathrm{C}$ at $20^{\circ} \mathrm{C} \mathrm{min}^{-1}$, held at $280^{\circ} \mathrm{C}$ for $20 \mathrm{~min}$. For the determination of analytes, a mass spectrometer (Agilent Technologies 5975C, upgraded with a triple-axis detector, Palo Alto, CA, USA) was used. The temperature of the ion source was $230^{\circ} \mathrm{C}$, the auxiliary temperature was $280^{\circ} \mathrm{C}$ and the quadrupole temperature was $150^{\circ} \mathrm{C}$. For qualitative determination, retention time and mass spectrum in SIM were used. One target and 2-3 qualifier ions, presented in Table 2, were used for each active substance. The calibration was performed to matrix match standards.

\section{Multiresidual LC-MS/MS method}

With this method, the samples were analysed within in a maximum period of six months after arrival at the laboratory. During this time, they were stored at $-20^{\circ} \mathrm{C}$. 


\section{Preparation of solutions}

Stock solutions of individual active substances in methanol were prepared with the concentrations $625 \mu \mathrm{g}$ pesticide $\mathrm{mL}^{-1}$. From 60 stock solutions, two mix solutions of all 60 active substances were prepared: one with a concentration of $3.125 \mu \mathrm{g} \mathrm{mL} \mathrm{L}^{-1}$ and the second one at LOQ of active substances. All solutions used to determine linearity, LOQs and perform calibration when samples were analysed, were prepared from a mix solution of $3.125 \mu \mathrm{g} \mathrm{mL}^{-1}$ with proper dilutions. For other validation parameters, a mixed solution with a concentration at LOQ was used.

\section{Extraction procedure}

The extraction procedure is the same as for the determination of chlorfenvinphos, coumaphos and thymol, except that to dry eluate, $2 \mathrm{ml}$ of methanol p.a. was added in the case of a sample preparation. In the case of matrix match standards, $2 \mathrm{ml}$ of working solutions with proper concentrations were added.

\section{Determination with LC-MS/MS}

The samples were analysed using a liquid chromatograph (Agilent Infinity 1290, Palo Ato, USA) on a Titan ${ }^{\mathrm{TM}} \mathrm{C} 1880 \mathrm{~A}$ column $(10 \mathrm{~cm} \times 2.1 \mathrm{~mm}, 1.9 \mu \mathrm{m})$, Supelco with the gradient of $0.1 \%$ formic acid (A) and $0.1 \%$ formic methanol (B). Each sample was injected twice, once in ESI+ and one in ESI- mode. For ESI+ mode, the flow was 0.4 $\mathrm{mL} \min ^{-1}$ and the gradient was as follows: start at $3 \% \mathrm{~B}$ and hold for $3 \mathrm{~min}$, increase to $100 \% \mathrm{~B}$ in $17 \mathrm{~min}$, hold $100 \% \mathrm{~B}$ for 5 minutes, decrease to $3 \% \mathrm{~B}$ in 3 minutes, post run 2 minutes at $3 \%$ B. For ESI- mode, the flow was $0.5 \mathrm{~mL} \mathrm{~min}^{-1}$ and the gradient was as follows: start at $15 \% \mathrm{~B}$, increase to $70 \% \mathrm{~B}$ in $4 \mathrm{~min}$, increase to $100 \mathrm{~B}$ in 1 minute, hold $100 \% \mathrm{~B}$ for 1 minutes, decrease to $15 \% \mathrm{~B}$ in 1 minute, post run 3 minutes at $3 \% \mathrm{~B}$. For 
the determination of analytes, a triple quadrupole mass spectrometer Agilent 6460 (Agilent Technologies Palo Alto, CA, USA) was used. The source temperature was $250^{\circ} \mathrm{C}$, gas flow $6 \mathrm{~L} \mathrm{~min}^{-1}$, sheath gas flow $10 \mathrm{~L} \mathrm{~min}^{-1}$, sheath gas temperature $375^{\circ} \mathrm{C}$ and nebuliser pressure 35 psi. Quadropole temperatures were $100^{\circ} \mathrm{C}$. For each compound, two transitions were monitored, and therefore fragmentor and collision cell parameters were optimised. The data on possible MRM transitions were found in EURL Pesticides Data pool accessible on the internet at https://www.eurl-pesticidesdatapool.eu/. Optimisation of fragmentor and collision cell voltages was performed using Agilent Optimizer software and standard solutions of active substances in methanol $\left(1 \mathrm{mg} \mathrm{L}^{-1}\right)$. For quantitative determination, retention time and Multi Reaction Monitoring (MRM), peak area ratios were used. MRM transitions, fragmentor and collision energy are presented in Table 3 . The calibration was performed to matrix match standards.

\section{Validation of methods}

\section{$L O Q$ and linearity}

The linearity was verified by using the matrix match standards (five repetitions for one concentration level, three to eight concentration levels for the calibration curve). The linearity and range were determined by linear regression, using the $\mathrm{F}$ test.

LOQs were estimated from chromatograms of matrix match standards. LOQs were chosen at $\mathrm{S} / \mathrm{N}=10$ at least.

MRLs for environmental pesticide residues are set in Regulation (EC) 396/2005. When MRLs are set at LOQ of the analytical method (this LOQ was gathered by different laboratories), in Regulation, * is added to mark this fact. Therefore, in cases where MRLs were marked with *, some of our LOQs were set at those MRLs. 


\section{Accuracy}

Checking the recoveries was used to verify accuracy. Blank honey was bought in store and analysed to prove that it contains no pesticide residues. Ten extracts of spiked blank honey were prepared for each spiking level, in the shortest period possible. Each extract was injected twice. The average of recoveries was calculated. According to requirements for method validation procedures (SANTE/11813/2017), acceptable mean recoveries are those within the range $70-120 \%$, with an associated repeatability of RSDr $\leq 20 \%$

According to the guidelines for single-laboratory validation (Alder et al. 2000), acceptable mean recoveries are:

- at level $>0.01 \mathrm{mg} \mathrm{kg}^{-1} \leq 0.1 \mathrm{mg} \mathrm{kg}^{-1}$ are those within the range $70-120 \%$, with an associated repeatability $\mathrm{RSDr} \leq 20 \%$ and - at level $>0.001 \mathrm{mg} \mathrm{kg}^{-1} \leq 0.01 \mathrm{mg} \mathrm{kg}^{-1}$ are those within the range $60-120 \%$, with an associated repeatability $\mathrm{RSDr} \leq 30 \%$.

The accuracy was also checked with participation in a proficiency testing scheme organised by BIPEA (Bureau interprofessionnel d'études analytiques).

\section{Precision}

For the determination of precision (ISO 5725), i.e. repeatability and reproducibility, the extracts of spiked blank honey were analysed at LOQ. Within a period of 10 days, two parallel extracts were prepared each day for each concentration level. Each one was injected once. Then, the standard deviation of the repeatability of the level and the standard deviation of reproducibility of the level were both calculated. 
Uncertainty of repeatability and uncertainty of reproducibility

The uncertainty of repeatability and the uncertainty of reproducibility were calculated by multiplying the standard deviation of repeatability and standard deviation of reproducibility by the Student's t factor, for 9 degrees of freedom and a $95 \%$ confidence level $\left(t_{95 ; 9}=2.262\right)$.

$\mathrm{U}_{\mathrm{r}}=\mathrm{t}_{95 ; 9} \mathrm{X \textrm {S } _ { \mathrm { r } }} ; \mathrm{U}_{\mathrm{R}}=\mathrm{t}_{95 ; 9} \mathrm{X \textrm {S } _ { \mathrm { R } }}$

The measurement uncertainty for PPP residues should be 50\%, as proposed in SANTE/11813/2017. With validation, analysts must prove that their measurement uncertainty is below or equal to the proposed measurement uncertainty.

\section{Consumer risk assessment}

\section{Chronic exposure}

The calculation of long-term exposure was performed with the EFSA PRIMo model revision 3 , accessible on the internet at https://www.efsa.europa.eu/en/applications/pesticides/tools. The Supervised Trial Median Residue (STMR) was calculated from all samples analysed. It was compared to the Acceptable Daily Intake (ADI) of a single active substance. Chronic consumer exposure was expressed in \% of the ADI. The acceptable limit for long-term exposure is $100 \%$ of the ADI.

\section{Acute exposure}

The calculation of short-term exposure was performed with the EFSA PRIMo model revision 3 , accessible on the internet at https://www.efsa.europa.eu/en/applications/pesticides/tools. 
The Highest Residue (HR) was compared to the Acute Reference Dose (ARfD) of a single active substance. Acute consumer exposure was expressed in $\%$ of ARfD. The acceptable limit for short-term exposure is $100 \%$ of the ARfD.

\section{Results and discussion}

\section{Comparison of method for determination of amitraz and all metabolites containing} the 2,4-dimethylaniline moiety from literature to our procedure

Our hydrolysis and extraction procedure is a modified procedure, as described by Jiménez et al. (2002). Our laboratory sample was bigger (10 g instead of $1 \mathrm{~g})$, our pH adjustment was performed firstly with $\mathrm{HCl}$ and then with $\mathrm{NaOH}$, instead of a one step adjustment with aqueous solution with $\mathrm{pH} 11$. Our extraction with n-hexane took place in a separatory funnel instead by sonication. Afterwards in our procedure, hydrolysis with $\mathrm{NaOH}$ at $90^{\circ} \mathrm{C}$ was not performed. Hydrolysis in our procedure took place during $\mathrm{pH}$ adjustment at room temperature. Finally in both procedures, HFBA was used for derivatisation.

\section{Validation of methods}

\section{$L O Q$ and linearity}

The linear model fits for all active substances presented in Tables 2 and 3 . In Table 4 is presented how many substances have linear response in certain range for GC/MS and LC-MS/MS determination. In general linearity was checked in the range $0.01-0.2 \mathrm{mg}$

$\mathrm{kg}^{-1}$ for GC/MS and in range $0.003-0.4 \mathrm{mg} / \mathrm{kg}$ for LC-MS/MS. $\mathrm{R}^{2}$ ranged from 0.960 to 0.988 for GC/MS determination and from 0.991 to 0.999 for LC-MS/MS determination. 
As expected, linearity ranges for active substances determined with GC/MS are mainly in a higher concentration range than the ones for active substances determined with LC-MS/MS.

LOQs are presented in Tables 2 and 3. For GC/MS determination 16 active substances have LOQ $0.01 \mathrm{mg} \mathrm{kg}^{-1}, 6$ of them $0.02 \mathrm{mg} \mathrm{kg}^{-1}, 3$ of them $0.03 \mathrm{mg} \mathrm{kg}^{-1}$ and 50 of them $0.05 \mathrm{mg} \mathrm{kg}^{-1}$. For LC-MS/MS determination 1 active substance has LOQ $0.003 \mathrm{mg} \mathrm{kg}^{-1}, 46$ of them $0.005 \mathrm{mg} \mathrm{kg}^{-1}$ and 13 of them $0.01 \mathrm{mg} \mathrm{kg}^{-1}$. LOQs are lower or equal to MRLs set in Regulation (EC) 396/2005 and Regulation (EC) 37/2010.

As expected, LOQs for active substances determined with GC/MS are mainly substantially higher than the ones for active substances determined with LC-MS/MS.

\section{Accuracy}

Results for recoveries are given in Tables 2 and 3. Recoveries at LOQs for active substances scanned with GC/MS are in the range of 77.4 to $99.2 \%$, with RSDs 5.4 to 16.7\%. More precisely, recoveries at LOQs $0.01 \mathrm{mg} \mathrm{kg}^{-1}$ are within the range of 77.5 to 94.2\% with RSDs 5.7 to $11.7 \%$ and recoveries at LOQs $>0.01$ to $\leq 0.05 \mathrm{mg} \mathrm{kg}^{-1}$ are within the range of 77.4 to $99.2 \%$ with RSDs 5.4 to $16.7 \%$.

Recoveries at LOQs, which are in the range of 0.003 to $0.01 \mathrm{mg} \mathrm{kg}^{-1}$, for active substances scanned with LC-MS/MS are in the range of 83.1 to $103.7 \%$, with RSDs 5.8 to $13.1 \%$.

All recoveries and RSDs are within the required ranges from literature (Alder et al. 2000; SANTE/11813/2017).

Recoveries for active substances determined with GC/MS are slightly lower than the ones determined with LC-MS/MS.

Accuracy was also checked by collaboration in the inter-laboratory proficiency test BIPEA. All our results are in the required range (-2 $\geq \mathrm{z} \leq 2) .15$ of 16 active 
substances ( $93.8 \%$ of analysed active substances) have $\mathrm{z}$ value in the range -1 to 1 , which is satisfactory. Only 1 active substance (acrinathrin) has $\mathrm{z}$ value lower than -1 , but it is still in the required range for correct result. Results are presented in Figure 1.

\section{Uncertainty of repeatability and uncertainty of reproducibility}

Uncertainty of repeatability and uncertainty of reproducibility were determined at contents equal to LOQs. Results are presented in Tables 2 and 3. For GC/MS determination of active substances, uncertainty of repeatability ranging from 0.0007 to $0.01 \mathrm{mg} \mathrm{kg}^{-1}$, which is 7.0 to $25.0 \%$ of LOQ and uncertainty of reproducibility ranging from 0.0007 to $0.02 \mathrm{mg} \mathrm{kg}^{-1}$, which is 7.0 to $40.0 \%$ of LOQ.

For LC-MS/MS determination of active substances, uncertainty of repeatability ranging from 0.0003 to $0.0015 \mathrm{mg} \mathrm{kg}^{-1}$, which is 6.2 to $18.0 \%$ of LOQ and uncertainty of reproducibility ranging from 0.0001 to $0.009 \mathrm{mg} \mathrm{kg}^{-1}$, which is 13.4 to $29.8 \%$ of LOQ.

The highest percentages of uncertainties of repeatability and of reproducibility are higher for active substances determined with GC/MS than for the ones determined with LC-MS/MS.

\section{Choosing of methods}

According to Regulation (EC) $37 / 2010$, amitraz has to be analysed as amitraz and all metabolites containing the 2,4-dimethylaniline moiety. This cannot be achieved with multiresidual method. Amitraz and metabolites in sample must be exposed to hydrolisys and derivatised to 2,4-dimethylaniline to enable measurement of valid residue definition. This is why the single residue method was introduced for amitraz. 
Beside method for amitraz, our laboratory firstly introduced GC/MS and LC-MS/MS multiresidual methods for determination of environmental pesticide residues. GC/MS method was tested for 92 active compounds in one chromatographic run. When validation took place 75 active substances passed all validation criteria. Since this method is used in laboratory for analyses of fruit and vegetables as well, active substances with unsatisfactory results were not removed from chromatographic run. Analyses of these active substances was found to be suitable for anylses of fruit and vegetables. 92 compounds in one chromatographic run resulted in crowd, which did not allow to insert 3 more substances. This is why separate chromatographic run was set for thymol, chlorfenvinphos and coumaphos.

\section{Applicability of methods}

The methods described above can be used in every laboratory dealing with pesticide residues and acaricide residues in honey. All methods are simple to perform. The main advantage is that the three methods have practically the same extraction procedure, meaning that the time needed for the preparation of samples can be substantially reduced. The second advantage is that a laboratory performing these methods does not need to be equipped with the GC/MS/MS or GC/MS with large volume injection, as in the case of the QuEChERS method. During the extraction procedure, analytes are concentrated to such a level, that the determination with the GC/MS is sensitive enough to find out conformity with the valid MRLs. The third advantage is that the method can be extended to a larger scope of the active substances than presented in this paper. The 
only disadvantage of the methods is that they require larger volumes of organic solvents, in comparison to the QuEChERS method.

\section{Survey of pesticide residues in honey samples}

The Slovenian Beekeepers' Association announced that in Slovenia, 11 veterinary drug residues, containing 6 active substances, are authorised to supress varroa. In our survey, we were checking for the presence of residues of most broadly used active substances: amitraz, coumaphos and thymol. Chlorfenvinphos was included, after ministry suspicion of its unauthorised use in the year 2016.

The Ministry of Agriculture, Forestry and Food reported that in Slovenia, 568 PPPs, containing 208 active substances, are authorised for use on different agricultural products. The Statistical office announced that in the year 2017, 1,087 tons of active substances were sold in Slovenia, where we have 476,000 hectares of cultivated agricultural area. This suggests broad use of PPPs among farmers. Since bees collect pollen, not only on flowers, acacia, spruce, sage, lime and chestnut, but also on agricultural products treated with PPPs, like oilseed rape, fruits,..., we wanted to research if that kind of pesticide residues are found in honey as well. We were searching for authorised (50\% of active substances sought) and non-authorised active substances in Slovenia, to cover the possible misuse of PPPs.

The survey results are presented in Table 5 and Figure 2. In samples from organic production, the active substance amitraz was found in 2 samples at a content of $0.01 \mathrm{mgkg}^{-1}$, representing $9.1 \%$ of the analysed samples from organic production. The active substance thymol was found in only 1 sample from organic production at a content of $0.43 \mathrm{mgkg}^{-1}$, representing $4.5 \%$ of the analysed samples from organic 
production. It was expected that thymol would be present in larger amount of samples in organic production, but beekeepers obviously prefer the use of formic acid and oxalic acid to supress varroa. The active substance thiacloprid was found in only 1 sample from organic production at a content of $0.018 \mathrm{mgkg}^{-1}$, representing $4.5 \%$ of the analysed samples from organic production. In Slovenia, thiacloprid is authorised (among others) for use on oilseed rape, apples, pears and ornamentals. These are the plants on which bees collect pollen. In spite of the organic production of honey, in which thiacloprid was found, bees obviously collected thiacloprid residues in their environment and brought it to their hive. Other measured active substances originating from veterinary drugs and other ones originating from the environment were $<\mathrm{LOQ}$.

In samples from conventional production, only the active substances amitraz, coumaphos and thymol were found $\geq \mathrm{LOQ}$. Other measured active substances originating from veterinary drugs and the ones originating from the environment were $<$ LOQ. In 9 samples from conventional production, residues were $<$ LOQ. Amitraz was measured in 14 samples (36.8\% of the analysed samples from conventional production). Coumaphos was measured in 13 samples (34.2\% of the analysed samples from conventional production). Thymol was measured in only 3 samples ( $7.9 \%$ of the analysed samples from conventional production). The reason why thymol was found not only in organic, but also in conventional production is, that beekeepers use more than one veterinary drug to supress varroa on many occasions. Beekeepers from conventional production are not restricted only to veterinary drugs containing amitraz and coumaphos. Since thymol is allowed in organic production and it is considered of no cause for concern for consumers, it is videly used also among beekeepers from conventional production. Multiple residues, more precisely residues of amitraz and 
coumaphos, were found only in 1 sample $(2.6 \%$ of the analysed samples from conventional production).

No MRL exceedances were observed in organic or in conventional production. The highest residue determined for amitraz represented $60 \%$ of the valid MRL. The highest residue determined for coumaphos represented $55 \%$ of the valid MRL. The residue determined for thiacloprid represented 9\% of the valid MRL.

A consumer risk assessment was performed with EFSA PRIMo model rev. 3.0, where 36 national diets from EU countries are included. This model was used, since Slovenia has not created its own food basket yet. In the process of registration of PPPs in Slovenia, the same model is used. Calculations were conducted for amitraz, thiacloprid and thymol. For coumaphos, no ADI and ARfD were set. In the case of amitraz in honey, the highest chronic exposure was observed in the German diet for children. It represented $0.1 \%$ of ADI. Acute exposure for amitraz in honey represented $4 \%$ of ARfD. In the case of thymol in honey, the highest chronic exposure was observed in the German diet for children. It represented $0.1 \%$ of ADI. Acute exposure for thymol in honey represented $2 \%$ of ARfD. In the case of thiacloprid in honey, the chronic exposure was $0 \%$ of ADI. Acute exposure for thiacloprid in honey represented $0.2 \%$ of ARfD. Based on these calculations, the conclusion was that the analysed honey samples are of no cause for concern for consumers.

Our results were compared with results from other scientific papers. Juan-Borrás et al. (2016) reported that amitraz was found in $100 \%$ of honey samples in Spain, with a content range of $0.002-0.050 \mathrm{mg} \mathrm{kg}^{-1}$, and coumaphos was found in $63.6 \%$ of samples measured in a range of $0.001-0.013 \mathrm{mg} \mathrm{kg}^{-1}$. Amitraz was present in a higher ratio of analysed samples than in Slovenia, but at a lower content range. Coumaphos was present in a slightly lower ratio of analysed samples than in Slovenia, but at a lower 
content range. On the other hand, in the same paper it was reported that chlorfenvinphos was present in $36.4 \%$ of samples in the range of $0.001-0.008 \mathrm{mg} \mathrm{kg}^{-1}$. In Slovenia, no chlorfenvinphos was found in this study. The reason for a high ratio of positive samples (mainly for amitraz and chlorfenvinphos) could be reporting results between LD and LOQ in a survey from Spain. Chiesa et al. (2016) observed coumaphos maximum content in honey samples in Italy of $0.00206 \mathrm{mg} \mathrm{kg}^{-1}$. Coumaphos was found in approximately $42 \%$ of samples. Ratio of positive samples is lower than in Slovenia but maximum content is not. Wiest et al. (2011) measured a maximum amitraz content of $0.026 \mathrm{mg} \mathrm{kg}^{-1}$. Amitraz was found in $4 \%$ of the French honey samples analysed. The maximum coumaphos content was $0.029 \mathrm{mg} \mathrm{kg}^{-1}$. Coumaphos was found in $77 \%$ of French honey samples analysed. Amitraz maximum content, as well as the ratio of positive samples, is lower than in Slovenia. The reason for a lower ratio of positive samples could be the higher LOQ for amitraz in France than in Slovenia. On the other hand, the maximum coumaphos content is lower than in Slovenia, but the ratio of positive samples is higher, in spite of a higher LOQ for the active substance in France in comparison to Slovenia. Gbylik-Sikorska et al. (2015) found neonicotionoide clothianidin in honey from Poland at a maximum content of $0.1928 \mathrm{mg} \mathrm{kg}^{-1}$, but no neonicotinoids imidacloprid and thiacloprid. On the contrary, in Slovenia we found neonicotinoide thiacloprid. Neoniciotinoide imidacloprid was not found in Slovenia as well. Valverde et al. (2018) found neonicotinoide thiamethoxam at a maximum content of $0.144 \mathrm{mg} \mathrm{kg}^{-1}$ in $21.4 \%$ of the analysed honey samples from Spain and neonicotinoide clothianidin at an approximate content of $0.045 \mathrm{mg} \mathrm{kg}^{-1}$ in $3.6 \%$ of the analysed honey samples from Spain, but no neonicotinoide thiacloprid. In Slovenia, neonicotinoide thiacloprid was found in $1.7 \%$ of all analysed samples in this survey and neonicotinoide thiamethoxam was found in none of them. 


\section{Conclusions}

In our research, 2 methods for the determination of veterinary drugs were introduced and validated: a) for the determination of amitraz, b) for the determination of coumaphos and thymol. Second method included determination of chlorfenvinphos, acaricide, which can originate from environment. Additionally 2 methods for the determination of pesticide residues originating from the environment were introduced and validated: a) multiresidual GC/MS method for the determination of 75 active substances, b) multriresidual LC-MS/MS method for the determination of 60 active substances. These methods were found to be fit for purpose.

All the methods were used in the analysis of 60 honey samples from Slovenian beekeepers: 22 from organic production and 38 from conventional production. One pesticide residue originating from the environment was found in one of these samples (insecticide thiacloprid), while about half of the samples contained residues of veterinary drugs: amitraz, coumaphos and/or thymol. Although the contents of amitraz and coumpahos were mainly higher than observed in literature, a risk assessment revealed that Slovenian honey samples are of no cause for concern for consumers.

\section{Acknowledgements}

The authors express their thanks to Danijela Cvijin and Sonja Dolinšek for their help with the preparation of the extracts. The authors also acknowledge the financial support from the Slovenian Research Agency and Ministry of Agriculture, Forestry and Food.

\section{Disclosure statement}

No potential conflict of interest was reported by the authors. 
Funding

Some of the achieved results were created within the Programme of measures in the field of beekeeping in the Republic of Slovenia in the years 2017-2019, which was financed from the funds of the state budget and the budget of the European Union. The work was also financially supported by the Slovenian Research Agency (research core funding No. P4-0133).

References:

Alder L, Hill A, Holland PT, Lantos J, Lee SM, MacNeil, JD, O'Rangers J, van Zoonen P, Ambrus A. 2000. Guidelines for single-laboratory validation of analytical methods for trace-level concentrations of organic chemicals, Principles and practices of method validation (ed.: A. Fajgelj, A. Ambrus). The Royal Society of Chemistry, pp. $179-252$.

Anastassiades M, Lehotay S J, Štajnbaher D, Schenck F J. 2003. Fast and easy multiresidue method employing acetonitrile extraction/partitioning and »dispersive solid-phase extraction « for the determination of pesticide residues in produce. J AOAC Int, 86: 412-431.

Andersson A, Pålsheden H. 1991. Comparison of the efficiency of different GLC multiresidue methods on crops containing pesticide residues. Fresen J Anal Chem, 339: 365367.

Anderson DL, Trueman JWH. 2000. Varroa jacobsoni (Acari: Varroidae) is more than one species. Exp Appl Acarol. 24: 165-189. 
Bargańska Ž, Ślebioda M, Namieśnik J. 2013. Pesticide residues levels in honey from apiaries located on Northern Poland. Food Control. 31: 196-201.

BIPEA. 2017a. Bureau interprofessionnel d'études analytiques. Laboratory comparisons report, Honey, 29-3619. October 2017. Gienevilliers, BIPEA.

BIPEA. 2017b. Bureau interprofessionnel d’études analytiques. Laboratory comparisons report, Honey, 30-3619. December 2017. Gienevilliers, BIPEA.

Calatayud-Vernich P, Calatayud F, Simó E, Suarez-Varela MM, Picó Y. 2016.

Influence of pesticide use in fruit orchards during blooming on honeybee mortality in 4 experimental apiaries. Sci Total Environ. 541: 33-41.

Chiesa LM, Labella GF, Giorgi A, Panseri S, Pavlovic R, Bonacci S, Arioli F. 2016. The occurence of pesticides and persistent organic pollutants in Italian organic honeys from different productive areas in relation to potential environmental pollution. Chemosphere. 154: 482-490.

Eckert JE. 1933. The flight range of the honeybee. J Agric Res. 47: 257-285.

Farajzadeh MA, Mogaddam MRA, Ghorbanpour H. 2014. Development of a new microextraction method based on elevated temperature dispersive liquid-liquid microextraction for determination of triazole pesticides residues in honey by gas chromatography-nitrogen phosphorus detection. J Chromatogr A. 1347: 8-16. 
Gbylik-Sikorska M, Sniegocki T, Posyniak A. 2015. Determination of neonicotinoid insecticides and their metabolites in honey bee and honey by liquid chromatography tandem mass spectrometry. J Chromatogr B. 990: 132-140.

ISO 5725. 1994. Accuracy (trueness and precision) of measurement methods and results - Part2: Basic method for the determination of repeatability and reproducibility of a standard measurement method, pp. 1-42.

Jiménez JJ, Nozal, MJ, Bernal JL, Santos M, Mayorga AL. 2002. Factors affecting the extraction, hydrolisis and derivatization steps for the quantification of total residues of amitraz in honey by gas chromatography with electron capture detection. Anal Bioanal Chem. 374: 300-304.

Jin Y, Zhang J, Zhao W, Zhang W, Wang L, Zhou J, Li Y. 2017. Development and validation of a multiclass method for the quantification of veterinary drug residues in honey and royal jelly by liquid chromatography-tandem mass spectrometry. Food Chem. 221: 1298-1307.

Juan-Borrás M, Domenech E, Escriche I. 2016. Mixture-risk-assessment of pesticide residues in retail polyfloral honey. Food Control. 67: 127-134.

Kujawski MW, Namieśnik J. 2011. Levels of 13 multi-class pesticide residues in Polish honeys determined by LC-ESI-MS/MS. Food Control. 22: 914-919. 
Luke M A, Froberg J E, Masumoto H T. 1975. Extraction and cleanup of organochlorine, organophosphate, organonitrogen, and hydrocarbon pesticides in produce for determination by gas-liquid chromatography. J of AOAC, 58: 1020-1026.

Malhat FM, Haggag N, Loutfy NM, Osman MAM, Ahmed MT. 2015. Residues of organochlorine and synthetic pyrethroid pesticides in honey, an indicator of ambient environment, a pilot study. Chemosphere. 120: 457-461.

Notardonto I, Avino P, Cinelli G, Russo MV. 2016. Rapid and reliable method for analyzing acaricides in honey-based products. Food Anal Method. 9: 1675-1685.

Panseri S, Catalano A, Giorgi A, Arioli F, Procopio A, Britti D, Chiesa LM. 2014. Occurence of pesticide residues in Italian honey from different areas in relation to its potential contamination sources. Food Control. 38: 150-156.

Rezaee M, Assadi Y, Hosseini M R M, Aghaee E, Ahmadi F, Berijani S. 2006. Determination of organic compounds in water using dispersive liquid-liquid microextraction. J Chromatogr A, 1116: 1-9.

Rodríguez López D, Ahumada DA, Consuelo Díaz A, Guerrero JA. 2014. Evaluation of pesticide residues in honey from different geographic regions of Colombia. Food Control. 37: 33-40. 
SANTE/11813/2017. Guidance document on analytical quality control and method validation procedures for pesticide residues analysis in food and feed. DG SANTE, European Comission, 2017.

Shamsipur M, Yazdanfar N, Ghambarian M. 2016. Combination of solid-phase extraction with dispersive liquid-liquid microextraction followed by GC-MS for determination of pesticide residues from water, milk, honey and fruit juice. Food Chem. 204: 289-297.

Shamsipur M, Hassan J, Salar-Amoli J, Yamini Y. 2008. Headspace solvent microextraction-gas chromatographic thermionic specific detector determination of amitraz in honey after hydrolysis to 2,4-dimethylaniline. J Food Compos Anal. 21: 264270.

Shendy AH, Al-Ghobashy MA, Mohammed MN, Gad Alla SA, Lotfy HM. 2016. Simultaneous determination of 200 pesticide residues in honey using gas chromatography-tandem mass spectrometry in conjunction with streamlined quantification approach. Journal Chromatogr A. 1427: 142-160.

Tette PAS, da Silva Oliveira FA, Pereira ENC, Silva G, de Abreu G, Fernandes C. 2016. Multiclass method for pesticides quantification in honey by means of modified QuEChERS and UHPLC-MS/MS. Food Chem. 211: 130-139.

Tomasini D, Sampaio MRF, Caldas SS, Buffon JG. 2012. Simultaneous determination of pesticides and 5-hydroxymethylfurfural in honey by the modified QuEChERS 
method and liquid chromatography coupled to tandem mass spectrometry. Talanta. 99: 380-386.

Vidal J L M, Liébanas F J A, Rodríguez M J G, Frenich A G, Moreno J L F. 2005. Validation of a gas chromatography/triple quadrupole mass spectrometry based method for the quantification of pesticides in food commodities. Rappid Commun Mass Sp, 20: 365-375.

Wang J, Kliks MM, Jun S, Li QX. 2010. Residues of organochlorine pesticides in honeys from different geographic regions. Food Res Int. 43: 2329-2334.

Wiest L, Buleté A, Giroud B, Fratta C, Amic S, Lambert O, Pouliquen H, Arnaudguilhem C. 2011. Multi-residue analysis of 80 environmental contaminants in honeys, honeybees and pollens by one extraction procedure followed by liquid and gas chromatography coupled with mass spectrometric detection. J Chromatogr A. 1218: $5743-5756$.

Valverde S, Ibáñez M, Bernal JL, Nozal MJ, Hernández F, Bernal J. 2018. Development and validation of ultra high performance-liquid chromatography-tandem mass spectrometry based methods for the determination of neonicotinoid insecticides in honey. Food Chem. 266: 215-222.

Zacharis CK, Rotsias I, Zachariadis PG, Zotos A. 2012. Dispersive liquid-liquid microextraction for the determination of organochlorine pesticides residues in honey by 
gas chromatography-electron capture and ion trap mass spectrometric detection. Food Chem. 134: 1665-1672.

Zhou X, Taylor MP, Davies PJ, Prasad S. 2018. Identifying Sources of Environmental Contamination in European Honey Bees (Apis mellifera) Using Trace Elements and Lead Isotopic Compositions. Environ Sci Technol. 52: 991-1001. 
Table 1: Number of samples collected from different statistical regions in Slovenia In 2017 and 2018.

\begin{tabular}{|c|c|c|c|c|c|}
\hline & \multicolumn{2}{|c|}{ Conventional production } & \multicolumn{2}{|c|}{ Organic production } & \multirow[t]{2}{*}{ Sum } \\
\hline Statistical region & 2017 & 2018 & 2017 & 2018 & \\
\hline Goriška & 1 & 1 & 1 & 1 & 4 \\
\hline Notranje kraška & 1 & 0 & 1 & 2 & 4 \\
\hline Zasavska & 0 & 0 & 0 & 1 & 1 \\
\hline Obalno kraška & 1 & 1 & 0 & 4 & 6 \\
\hline Gorenjska & 1 & 0 & 0 & 0 & 1 \\
\hline Koroška & 4 & 3 & 1 & 0 & 8 \\
\hline Jugovzhodna Slovenija & 0 & 4 & 0 & 0 & 4 \\
\hline Podravska & 4 & 4 & 3 & 0 & 11 \\
\hline Spodnje posavska & 1 & 0 & 0 & 1 & 2 \\
\hline Pomurska & 2 & 1 & 1 & 1 & 5 \\
\hline Osrednja Slovenija & 1 & 1 & 2 & 1 & 5 \\
\hline Savinjska & 4 & 3 & 1 & 1 & 9 \\
\hline Sum & 20 & 18 & 10 & 12 & 60 \\
\hline
\end{tabular}


Table 2. Validation parameters for GC/MS determination, ions scanned and MRLs

\begin{tabular}{|c|c|c|c|c|c|c|c|c|c|c|c|}
\hline Active substance & $\begin{array}{l}\mathrm{MRL}^{\mathrm{a}, \mathrm{b}} \\
\left(\mathrm{mg} \mathrm{kg}^{-1}\right)\end{array}$ & $\begin{array}{c}\text { Ions scanned }(\mathrm{m} / \mathrm{z}) \\
\mathrm{T}, \mathrm{Q}_{1}, \mathrm{Q}_{2}, \mathrm{Q}_{3} \\
\end{array}$ & $\begin{array}{l}\text { Linearity } \\
\text { range } \\
\left(\mathrm{mg} \mathrm{kg}^{-1}\right)\end{array}$ & $\mathrm{R}^{2}$ & $\begin{array}{c}\text { LOQ } \\
\left(\mathrm{mg} \mathrm{kg}^{-1}\right)\end{array}$ & $\begin{array}{c}\text { Recovery } \\
(\%)\end{array}$ & $\begin{array}{r}\text { RSD } \\
(\%) \\
\end{array}$ & $\begin{array}{c}\mathrm{U}_{\mathrm{r}} \text { (refer to } \\
\left(\mathrm{mg} \mathrm{kg}^{-1}\right) \\
\end{array}$ & \begin{tabular}{|c|}
$\begin{array}{c}\mathrm{U}_{\mathrm{r}}^{\text {(egender to }} \\
\text { (egend }\end{array}$ \\
$(\%)$ \\
\end{tabular} & $\begin{array}{c}\mathrm{U}_{\mathrm{R}} \text { (refer to } \\
\text { legend) } \\
\left(\mathrm{mg} \mathrm{kg}^{-1}\right)\end{array}$ & $\begin{array}{c}\mathrm{U}_{\mathrm{R}}{ }^{\text {(refer }} \\
\text { to legend) } \\
(\%) \\
\end{array}$ \\
\hline acrinathrin & $0.05^{* \mathrm{a}}$ & $181,208,289$ & $0.02-0.15$ & 0.978 & 0.02 & \begin{tabular}{|l|}
94.7 \\
\end{tabular} & 6.6 & 0.003 & 15.0 & 0.003 & 15.0 \\
\hline amitraz & $0.2^{\mathrm{b}}$ & $148,317,120$ & $0.01-0.3$ & 0.994 & 0.01 & 102.9 & 4.6 & 0.001 & 10.0 & 0.002 & 20.0 \\
\hline azinphos-methyl & 1 & $160,132,105$ & $0.01-0.15$ & 0.984 & 0.01 & 81.2 & 7.2 & 0.001 & 10.0 & 0.001 & 10.0 \\
\hline azoxystrobin & $0.05^{* \mathrm{a}}$ & $344,388,345$ & $0.05-0.15$ & 0.976 & 0.05 & 83.5 & 13.9 & 0.010 & 20.0 & 0.010 & 20.0 \\
\hline bromopropylate & $0.01^{* \mathrm{a}}$ & $183,341,185$ & $0.01-0.15$ & 0.982 & 0.01 & 92.4 & 7.5 & 0.001 & 10.0 & 0.001 & 10.0 \\
\hline bupirimate & $0.05 *^{\mathrm{a}}$ & $273,316,208$ & $0.05-0.15$ & 0.972 & 0.05 & 77.6 & 11.3 & 0.008 & 16.0 & 0.009 & 18.0 \\
\hline captan & $0.05^{* \mathrm{a}}$ & $79,107,119,149$ & $0.05-0.15$ & 0.972 & 0.05 & 88.9 & 5.9 & 0.009 & 18.0 & 0.015 & 30.0 \\
\hline carbaryl & $0.05^{* \mathrm{a}}$ & $144,115,116$ & $0.05-0.15$ & 0.973 & 0.05 & 85.8 & 8.2 & 0.006 & 12.0 & 0.007 & 14.0 \\
\hline carbofuran & $0.05^{* \mathrm{a}}$ & $164,149,131$ & $0.03-0.15$ & 0.987 & 0.03 & 82.1 & 7.2 & 0.004 & 13.3 & 0.004 & 13.3 \\
\hline chlorpyriphos-methyl & $0.05^{* \mathrm{a}}$ & $286,288,125$ & $0.01-0.15$ & 0.983 & 0.01 & 88.2 & 5.7 & 0.0008 & 8.0 & 0.0008 & 8.0 \\
\hline coumaphos & $0.1^{\mathrm{b}}$ & $362,364,226,210$ & $0.009-0.45$ & 0.985 & 0.009 & 89.1 & 8.6 & 0.0013 & 14.4 & 0.0013 & 14.4 \\
\hline cyhalotrin-lambda & $0.05^{*^{\mathrm{a}}}$ & $181,197,208$ & $0.05-0.15$ & 0.977 & 0.05 & 89.9 & 6.7 & 0.006 & 12.0 & 0.006 & 12.0 \\
\hline cypermethrin & $0.05^{*^{\mathrm{a}}}$ & $181,163,165$ & $0.05-0.15$ & 0.967 & 0.05 & 93.5 & 7.1 & 0.007 & 14.0 & 0.008 & 16.0 \\
\hline
\end{tabular}




\begin{tabular}{|c|c|c|c|c|c|c|c|c|c|c|c|}
\hline Active substance & $\begin{array}{l}\mathrm{MRL}^{\mathrm{a}, \mathrm{b}} \\
\left(\mathrm{mg} \mathrm{kg}^{-1}\right)\end{array}$ & $\begin{array}{c}\text { Ions scanned (m/z) } \\
\mathrm{T}, \mathrm{Q}_{1}, \mathrm{Q}_{2}, \mathrm{Q}_{3}\end{array}$ & $\begin{array}{c}\text { Linearity } \\
\text { range } \\
\left(\mathrm{mg} \mathrm{kg}^{-1}\right)\end{array}$ & $\mathrm{R}^{2}$ & $\begin{array}{c}\text { LOQ } \\
\left(\mathrm{mg} \mathrm{kg}^{-1}\right)\end{array}$ & $\begin{array}{c}\text { Recovery } \\
(\%) \\
\end{array}$ & $\begin{array}{l}\text { RSD } \\
(\%)\end{array}$ & $\begin{array}{c}\begin{array}{c}\mathrm{r} \\
\text { legend) }\end{array} \\
\left(\mathrm{mg} \mathrm{kg}^{-1}\right) \\
\end{array}$ & $\begin{array}{c}\begin{array}{c}\mathrm{U}_{\mathrm{r}} \text { (refer to } \\
\text { legend) }\end{array} \\
(\%)\end{array}$ & $\begin{array}{c}\mathrm{U}_{\mathrm{R}} \text { (refer to } \\
\text { legend) } \\
\left(\mathrm{mg} \mathrm{kg}^{-1}\right) \\
\end{array}$ & $\begin{array}{c}\mathrm{U}_{\mathrm{R}} \text { (refer } \\
\text { to legend) } \\
(\%) \\
(\%)\end{array}$ \\
\hline cyproconazole & $0.05 *^{\mathrm{a}}$ & $222,139,224$ & $0.05-0.15$ & 0.973 & 0.05 & 82.7 & 9.0 & 0.008 & 16.0 & 0.008 & 16.0 \\
\hline cyprodinil & $0.05 *^{\mathrm{a}}$ & $224,225,210$ & $0.05-0.15$ & 0.974 & 0.05 & 84.2 & 7.2 & 0.006 & 12.0 & 0.006 & 12.0 \\
\hline deltamethrin & $0.05^{* \mathrm{a}}$ & $181,251,255$ & $0.03-0.15$ & 0.983 & 0.03 & 92.9 & 7.8 & 0.004 & 13.3 & 0.004 & 13.3 \\
\hline diazinon & $0.01 *^{\mathrm{a}}$ & $179,304,199$ & $0.01-0.15$ & 0.985 & 0.01 & 84.7 & 8.5 & 0.001 & 10.0 & 0.001 & 10.0 \\
\hline dichlofluanid & I & $226,123,167$ & $0.05-0.15$ & 0.975 & 0.05 & 87.3 & 6.0 & 0.004 & 8.0 & 0.004 & 8.0 \\
\hline dichlorvos & I & $109,185,145$ & $0.02-0.1$ & 0.982 & 0.02 & 83.0 & 16.7 & 0.005 & 25.0 & 0.006 & 30.0 \\
\hline dimethachlor & $0.05 *^{\mathrm{a}}$ & $134,197,210$ & $0.01-0.15$ & 0.983 & 0.01 & 94.2 & 9.7 & 0.001 & 10.0 & 0.002 & 20.0 \\
\hline dimethoate & I & $87,229,143$ & $0.03-0.15$ & 0.980 & 0.03 & 80.7 & 7.8 & 0.005 & 16.7 & 0.007 & 23.3 \\
\hline diniconazole & $0.05 *^{\mathrm{a}}$ & $268,270,70$ & $0.05-0.15$ & 0.972 & 0.05 & 84.1 & 7.5 & 0.007 & 14.0 & 0.007 & 14.0 \\
\hline endrin & $0.01^{\mathrm{a}}$ & $263,261,265$ & $0.01-0.15$ & 0.984 & 0.01 & 89.3 & 6.2 & 0.001 & 10.0 & 0.001 & 10.0 \\
\hline esfenvalerate + fenvalerate & $0.05 *^{\mathrm{a}}$ & $125,167,225$ & $0.05-0.15$ & 0.971 & 0.05 & 99.2 & 7.5 & 0.007 & 14.0 & 0.007 & 14.0 \\
\hline fenamidone & $0.05 *^{\mathrm{a}}$ & $238,268,237$ & $0.05-0.15$ & 0.974 & 0.05 & 84.1 & 7.8 & 0.007 & 14.0 & 0.007 & 14.0 \\
\hline fenbuconazole & $0.05 *^{\mathrm{a}}$ & $198,129,125$ & $0.05-0.15$ & 0.974 & 0.05 & 83.0 & 13.0 & 0.010 & 20.0 & 0.010 & 20.0 \\
\hline fenthion & $0.01 *^{\mathrm{a}}$ & $278,279,280$ & $0.01-0.15$ & 0.985 & 0.01 & 89.6 & 6.0 & 0.001 & 10.0 & 0.001 & 10.0 \\
\hline flonicamid & $0.05 *^{\mathrm{a}}$ & $174,146,229$ & $0.05-0.2$ & 0.982 & 0.05 & 78.2 & 11.4 & 0.009 & 18.0 & 0.010 & 20.0 \\
\hline fludioxonil & $0.05 *^{\mathrm{a}}$ & $248,154,127$ & $0.05-0.15$ & 0.969 & 0.05 & 83.6 & 7.3 & 0.008 & 16.0 & 0.008 & 16.0 \\
\hline fluquinconazole & $0.02 *^{\mathrm{a}}$ & $340,342,108$ & $0.02-0.15$ & 0.982 & 0.02 & 85.0 & 9.9 & 0.003 & 15.0 & 0.003 & 15.0 \\
\hline folpet & $0.05 *^{\mathrm{a}}$ & $260,262,130$ & $0.05-0.15$ & 0.971 & 0.05 & 88.5 & 6.0 & 0.010 & 20.0 & 0.020 & 40.0 \\
\hline heptachlor & $0.01^{\mathrm{a}}$ & $272,274,270$ & $0.01-0.15$ & 0.985 & 0.01 & 89.0 & 6.0 & 0.0007 & 7.0 & 0.0008 & 8.0 \\
\hline hexachlorobenzene & $0.01 *^{\mathrm{a}}$ & $284,286,282$ & $0.01-0.15$ & 0.985 & 0.01 & 84.7 & 7.2 & 0.0008 & 8.0 & 0.0009 & 9.0 \\
\hline indoxacarb & $0.05 *^{\mathrm{a}}$ & $218,264,527$ & $0.05-0.15$ & 0.976 & 0.05 & 89.9 & 8.9 & 0.008 & 16.0 & 0.008 & 16.0 \\
\hline iprodione & $0.05^{*^{\mathrm{a}}}$ & $314,316,187$ & $0.05-0.15$ & 0.974 & 0.05 & 86.4 & 7.2 & 0.006 & 12.0 & 0.007 & 14.0 \\
\hline kresoxim-methyl & $0.05 *^{\mathrm{a}}$ & $116,206,131$ & $0.05-0.15$ & 0.974 & 0.05 & 87.3 & 5.7 & 0.005 & 10.0 & 0.005 & 10.0 \\
\hline malathion & $0.05^{* \mathrm{a}}$ & $173,174,211$ & $0.05-0.15$ & 0.974 & 0.05 & 86.6 & 5.6 & 0.005 & 10.0 & 0.005 & 10.0 \\
\hline
\end{tabular}




\begin{tabular}{|c|c|c|c|c|c|c|c|c|c|c|c|}
\hline Active substance & $\begin{array}{l}\mathrm{MRL}^{\mathrm{a}, \mathrm{b}} \\
\left(\mathrm{mg} \mathrm{kg}^{-1}\right)\end{array}$ & $\begin{array}{c}\text { Ions scanned }(\mathrm{m} / \mathrm{z}) \\
\mathrm{T}, \mathrm{Q}_{1}, \mathrm{Q}_{2}, \mathrm{Q}_{3}\end{array}$ & $\begin{array}{l}\text { Linearity } \\
\text { range } \\
\left(\mathrm{mg} \mathrm{kg}^{-1}\right)\end{array}$ & $\mathrm{R}^{2}$ & $\begin{array}{c}\mathrm{LOQ} \\
\left(\mathrm{mg} \mathrm{kg}^{-1}\right)\end{array}$ & $\begin{array}{c}\text { Recovery } \\
(\%)\end{array}$ & $\begin{array}{c}\mathrm{RSD} \\
(\%) \\
\end{array}$ & $\begin{array}{l}\mathrm{U}_{\mathrm{r}} \text { (refer to } \\
\left(\mathrm{mg} \mathrm{kg}^{-1}\right)\end{array}$ & $\begin{array}{c}\mathrm{U}_{\mathrm{r}} \text { legend) } \\
(\%) \\
(\%)\end{array}$ & $\begin{array}{c}\mathrm{U}_{\mathrm{R}} \text { (refer to } \\
\left(\mathrm{mg} \mathrm{kg}^{-1}\right) \\
\left(\mathrm{mg} \mathrm{h}^{-1}\right)\end{array}$ & $\begin{array}{c}\mathrm{U}_{\mathrm{R}} \text { (refer } \\
\text { to legend) } \\
(\%)\end{array}$ \\
\hline mecarbam & $0.05^{*^{\mathrm{a}}}$ & $131,159,329$ & $0.05-0.15$ & 0.974 & 0.05 & 87.1 & 5.9 & 0.005 & 10.0 & 0.005 & 10.0 \\
\hline metalaxyl+metalaxyl-M & $0.05 *^{\mathrm{a}}$ & $249,206,234$ & $0.05-0.15$ & 0.974 & 0.05 & 83.5 & 8.7 & 0.007 & 14.0 & 0.008 & 16.0 \\
\hline methacrifos & $0.05^{* a}$ & $208,180,240$ & $0.05-0.15$ & 0.977 & 0.05 & 97.0 & 14.5 & 0.006 & 12.0 & 0.008 & 16.0 \\
\hline methidathion & $0.02 *^{\mathrm{a}}$ & $145,85,125$ & $0.02-0.15$ & 0.977 & 0.02 & 84.0 & 10.5 & 0.002 & 10.0 & 0.002 & 10.0 \\
\hline metrafenone & $0.05^{* a}$ & $393,408,379$ & $0.05-0.15$ & 0.977 & 0.05 & 88.3 & 6.7 & 0.006 & 12.0 & 0.006 & 12.0 \\
\hline myclobutanil & $0.05^{*^{\mathrm{a}}}$ & $179,288,150$ & $0.05-0.15$ & 0.970 & 0.05 & 81.1 & 9.6 & 0.008 & 16.0 & 0.009 & 18.0 \\
\hline oxadixyl & $0.01 *^{\mathrm{a}}$ & $163,105,132$ & $0.01-0.15$ & 0.982 & 0.01 & 77.5 & 11.7 & 0.002 & 20.0 & 0.002 & 20.0 \\
\hline parathion & I & $291,292,235$ & $0.01-0.15$ & 0.984 & 0.01 & 87.6 & 8.1 & 0.001 & 10.0 & 0.001 & 10.0 \\
\hline penconazole & $0.05^{* a}$ & $248,159,161$ & $0.05-0.15$ & 0.972 & 0.05 & 84.7 & 7.1 & 0.006 & 12.0 & 0.007 & 14.0 \\
\hline permethrin & I & $183,163,165$ & $0.02-0.15$ & 0.987 & 0.02 & 89.8 & 5.9 & 0.002 & 10.0 & 0.002 & 10.0 \\
\hline phosalone & $0.01 *^{\mathrm{a}}$ & $182,367,121$ & $0.01-0.15$ & 0.982 & 0.01 & 90.6 & 10.1 & 0.001 & 10.0 & 0.001 & 10.0 \\
\hline pirimicarb & $0.05^{*^{\mathrm{a}}}$ & $166,238,167$ & $0.05-0.15$ & 0.979 & 0.05 & 79.5 & 11.6 & 0.009 & 18.0 & 0.010 & 20.0 \\
\hline pirimiphos-methyl & $0.05^{* a}$ & $290,305,276$ & $0.05-0.15$ & 0.977 & 0.05 & 87.5 & 6.0 & 0.004 & 8.0 & 0.004 & 8.0 \\
\hline procymidone & $0.05^{* a}$ & $283,285,96$ & $0.05-0.15$ & 0.973 & 0.05 & 86.7 & 5.5 & 0.005 & 10.0 & 0.005 & 10.0 \\
\hline profenofos & $0.05^{* \mathrm{a}}$ & $208,139,339$ & $0.05-0.15$ & 0.973 & 0.05 & 86.9 & 5.4 & 0.005 & 10.0 & 0.006 & 12.0 \\
\hline propargite & $0.05^{*^{\mathrm{a}}}$ & $135,173,350,201$ & $0.05-0.2$ & 0.971 & 0.05 & 86.6 & 5.9 & 0.006 & 12.0 & 0.006 & 12.0 \\
\hline propyzamide & $0.05^{* \mathrm{a}}$ & $173,175,145$ & $0.05-0.15$ & 0.976 & 0.05 & 84.0 & 6.4 & 0.005 & 10.0 & 0.005 & 10.0 \\
\hline pyridaphenthion & I & $199,340,188$ & $0.01-0.15$ & 0.986 & 0.01 & 84.4 & 8.2 & 0.001 & 10.0 & 0.001 & 10.0 \\
\hline pyrimethanil & $0.05 *^{\mathrm{a}}$ & $198,199,200$ & $0.05-0.1$ & 0.960 & 0.05 & 84.9 & 6.3 & 0.008 & 16.0 & 0.008 & 16.0 \\
\hline quinalphos & $0.05^{* a}$ & $146,298,157$ & $0.05-0.15$ & 0.974 & 0.05 & 86.5 & 5.6 & 0.005 & 10.0 & 0.005 & 10.0 \\
\hline quinoclamine & $0.05^{* a}$ & $207,172,209$ & $0.05-0.15$ & 0.964 & 0.05 & 77.4 & 5.9 & 0.005 & 10.0 & 0.008 & 16.0 \\
\hline quinoxyfen & $0.05^{*^{a}}$ & $237,272,307$ & $0.05-0.15$ & 0.977 & 0.05 & 85.1 & 6.1 & 0.006 & 12.0 & 0.006 & 12.0 \\
\hline tebuconazole & $0.05^{*^{a}}$ & $125,250,127$ & $0.05-0.15$ & 0.973 & 0.05 & 83.7 & 8.3 & 0.009 & 18.0 & 0.009 & 18.0 \\
\hline tetraconazole & $0.02 *^{\mathrm{a}}$ & $336,338,337$ & $0.02-0.15$ & 0.979 & 0.02 & 83.8 & 9.1 & 0.003 & 15.0 & 0.003 & 15.0 \\
\hline
\end{tabular}




\begin{tabular}{|c|c|c|c|c|c|c|c|c|c|c|c|}
\hline Active substance & $\begin{array}{l}\mathrm{MRL}^{\mathrm{a}, \mathrm{b}} \\
\left(\mathrm{mg} \mathrm{kg}^{-1}\right)\end{array}$ & $\begin{array}{c}\text { Ions scanned }(\mathrm{m} / \mathrm{z}) \\
\mathrm{T}, \mathrm{Q}_{1}, \mathrm{Q}_{2}, \mathrm{Q}_{3}\end{array}$ & $\begin{array}{l}\text { Linearity } \\
\text { range } \\
\left(\mathrm{mg} \mathrm{kg}^{-1}\right)\end{array}$ & $\mathrm{R}^{2}$ & $\begin{array}{c}\text { LOQ } \\
\left(\mathrm{mg} \mathrm{kg}^{-1}\right)\end{array}$ & $\begin{array}{c}\text { Recovery } \\
(\%)\end{array}$ & $\begin{array}{c}\mathrm{RSD} \\
(\%)\end{array}$ & $\begin{array}{c}\mathrm{U}_{\mathrm{r}} \text { legend) } \\
\left(\mathrm{mg} \mathrm{kg}^{-1}\right)\end{array}$ & $\begin{array}{c}\mathrm{U}_{\mathrm{r}}^{\text {legend) }} \\
(\%) \\
(\%)\end{array}$ & $\begin{array}{c}\mathrm{U}_{\mathrm{R}} \text { (refer to } \\
\text { legend) } \\
\left(\mathrm{mg} \mathrm{kg}^{-1}\right)\end{array}$ & $\begin{array}{c}\mathrm{U}_{\mathrm{R}}{ }^{\text {refer }} \\
\text { to legend) } \\
(\%) \\
\end{array}$ \\
\hline tetradifon & $0.05^{*^{\mathrm{a}}}$ & $159,229,356$ & $0.05-0.15$ & 0.977 & 0.05 & 88.1 & 5.9 & 0.005 & 10.0 & 0.006 & 12.0 \\
\hline thymol & I & $135,150,91$ & $0.07-3.5$ & 0.996 & 0.07 & 74.1 & 5.8 & 0.012 & 17.1 & 0.013 & 18.6 \\
\hline tolclofos-methyl & $0.05^{* \mathrm{a}}$ & $265,267,250$ & $0.05-0.15$ & 0.976 & 0.05 & 87.5 & 5.9 & 0.004 & 8.0 & 0.004 & 8.0 \\
\hline tolylfluanid & $0.05^{* \mathrm{a}}$ & $238,137,240$ & $0.05-0.15$ & 0.975 & 0.05 & 87.8 & 5.5 & 0.005 & 10.0 & 0.005 & 10.0 \\
\hline triadimefon & $0.05 *^{\mathrm{a}}$ & $208,210,181$ & $0.05-0.15$ & 0.973 & 0.05 & 85.1 & 6.6 & 0.006 & 12.0 & 0.006 & 12.0 \\
\hline triadimenol & $0.05^{*^{\mathrm{a}}}$ & $112,168,128$ & $0.05-0.15$ & 0.962 & 0.05 & 83.7 & 9.1 & 0.007 & 14.0 & 0.009 & 18.0 \\
\hline triazophos & $0.05^{* \mathrm{a}}$ & $161,162,285$ & $0.01-0.15$ & 0.988 & 0.01 & 86.5 & 6.0 & 0.002 & 20.0 & 0.002 & 20.0 \\
\hline trifloxystrobin & $0.05^{* \mathrm{a}}$ & $116,222,186$ & $0.05-0.15$ & 0.978 & 0.05 & 87.8 & 6.3 & 0.005 & 10.0 & 0.005 & 10.0 \\
\hline vinclozolin & $0.05^{* \mathrm{a}}$ & $285,124,187$ & $0.05-0.15$ & 0.976 & 0.05 & 87.9 & 5.5 & 0.004 & 8.0 & 0.004 & 8.0 \\
\hline
\end{tabular}

${ }^{a}$ Regulation (EC) 396/2005

${ }^{\mathrm{b}}$ Regulation (EC) 37/2010

* means that MRL is set at LOQ of analytical method

$\mathrm{T}$ is target ion

$\mathrm{Q}$ is qualifier ion

RSD was obtained during recovery analyses

$\mathrm{U}_{\mathrm{r}}$ is uncertainty of repeatability

$\mathrm{U}_{\mathrm{R}}$ is uncertainty of reproducibility 
Table 3: Validation parameters for LC-MS/MS determination, fragmentor (F), collision energy (CE), MRM transitions and MRLs

\begin{tabular}{|c|c|c|c|c|c|c|c|c|c|c|c|c|c|}
\hline Active substance & $\begin{array}{l}\mathrm{MRL}^{\mathrm{a}, \mathrm{b}} \\
\left(\mathrm{mg} \mathrm{kg}^{-1}\right)\end{array}$ & $\begin{array}{c}\mathrm{F} \\
(\mathrm{V})\end{array}$ & $\begin{array}{l}\mathrm{CE} \\
\text { (V) }\end{array}$ & $\begin{array}{c}\text { MRM } \\
\text { transitions } \\
(\mathrm{m} / \mathrm{z})\end{array}$ & $\begin{array}{l}\text { Linearity } \\
\text { range } \\
\left(\mathrm{mg} \mathrm{kg}^{-1}\right)\end{array}$ & $\mathrm{R}^{2}$ & $\begin{array}{c}\text { LOQ } \\
\left(\mathrm{mg} \mathrm{kg}^{-1}\right)\end{array}$ & $\begin{array}{c}\text { Recovery } \\
(\%)\end{array}$ & $\begin{array}{l}\mathrm{RSD} \\
(\%)\end{array}$ & $\begin{array}{l}\mathrm{U}_{\mathrm{r}} \text { (refer to } \\
\left(\mathrm{mg} \mathrm{kg}^{-1}\right)\end{array}$ & \begin{tabular}{|c|}
$\begin{array}{c}\mathrm{U}_{\mathrm{r}}^{\text {(refer }} \\
\text { to legend) }\end{array}$ \\
$(\%)$
\end{tabular} & $\begin{array}{l}\mathrm{U}_{\mathrm{R}}^{\text {legend })} \\
\left(\mathrm{mg} \mathrm{kg}^{-1}\right)\end{array}$ & $\begin{array}{c}\mathrm{U}_{\mathrm{R}} \text { (refer } \\
\text { to legend) } \\
(\%)\end{array}$ \\
\hline $\begin{array}{l}\text { 3-hydroxy } \\
\text { carbofuran }\end{array}$ & $0.05^{*^{\mathrm{a}}}$ & 100 & $\begin{array}{c}5 \\
10\end{array}$ & $\begin{array}{l}238 \rightarrow 181 \\
238-163\end{array}$ & $0.005-0.16$ & 0.997 & 0.005 & 91.4 & 5.8 & 0.0005 & 10.0 & 0.0007 & 13.4 \\
\hline acetamiprid & $0.05^{*^{\mathrm{a}}}$ & 126 & $\begin{array}{l}15 \\
15\end{array}$ & $\begin{array}{c}223->126 \\
223 \rightarrow 56\end{array}$ & $0.005-0.08$ & 0.998 & 0.005 & 92.9 & 7.8 & 0.0004 & 7.8 & 0.0007 & 17.9 \\
\hline beflubutamid & $0.05^{*^{\mathrm{a}}}$ & 115 & $\begin{array}{l}20 \\
40\end{array}$ & $\begin{array}{c}356-162 \\
356 \rightarrow 91\end{array}$ & $0.005-0.08$ & 0.996 & 0.005 & 94.9 & 8.9 & 0.0006 & 12.0 & 0.0011 & 21.5 \\
\hline benalaxyl & l & 120 & $\begin{array}{c}5 \\
10 \\
\end{array}$ & $\begin{array}{l}326 \rightarrow 294 \\
326 \rightarrow 148\end{array}$ & $0.005-0.08$ & 0.997 & 0.005 & 94.1 & 7.9 & 0.0006 & 10.2 & 0.0010 & 18.2 \\
\hline bitertanol & $0.05^{* \mathrm{a}}$ & 60 & $\begin{array}{l}1 \\
5\end{array}$ & $\begin{array}{c}338->269 \\
338->70\end{array}$ & $0.005-0.2$ & 0.996 & 0.005 & 92.8 & 9.5 & 0.0007 & 13.9 & 0.0012 & 22.0 \\
\hline carbendazim & $1.0^{\mathrm{a}}$ & 120 & $\begin{array}{l}15 \\
35\end{array}$ & $\begin{array}{l}192 \rightarrow 160 \\
192->132\end{array}$ & $0.005-0.08$ & 0.991 & 0.005 & 83.1 & 8.5 & 0.0004 & 8.6 & 0.0008 & 18.0 \\
\hline chlorotoluron & $0.05^{*^{\mathrm{a}}}$ & 100 & $\begin{array}{l}15 \\
15\end{array}$ & $\begin{array}{c}213->140 \\
213 \rightarrow 72\end{array}$ & $0.01-0.08$ & 0.991 & 0.01 & 103.7 & 8.4 & 0.0009 & 9.5 & 0.0020 & 21.0 \\
\hline $\begin{array}{l}\text { demeton-S-methyl } \\
\text { sulphone }\end{array}$ & $0.01 *^{\mathrm{a}}$ & 120 & $\begin{array}{l}15 \\
25 \\
\end{array}$ & $\begin{array}{l}263-169 \\
263->125\end{array}$ & $0.005-0.20$ & 0.995 & 0.005 & 92.9 & 8.6 & 0.0005 & 8.4 & 0.0011 & 19.9 \\
\hline desmedipham & $0.05^{*^{\mathrm{a}}}$ & 130 & $\begin{array}{c}5 \\
25\end{array}$ & $\begin{array}{l}301 \rightarrow 182 \\
301 \rightarrow 136\end{array}$ & $0.005-0.08$ & 0.993 & 0.005 & 94.1 & 9.0 & 0.0005 & 10.1 & 0.0011 & 20.8 \\
\hline difenoconazole & $0.05^{*^{\mathrm{a}}}$ & 140 & $\begin{array}{l}15 \\
25\end{array}$ & $\begin{array}{l}406-337 \\
406->251\end{array}$ & $0.005-0.20$ & 0.996 & 0.005 & 92.7 & 7.9 & 0.0008 & 15.1 & 0.0010 & 18.1 \\
\hline diflufenican & $0.05^{*^{\mathrm{a}}}$ & 110 & $\begin{array}{l}20 \\
40 \\
\end{array}$ & $\begin{array}{l}395-266 \\
395->238\end{array}$ & $0.005-0.08$ & 0.994 & 0.005 & 94.0 & 9.5 & 0.0008 & 15.6 & 0.0012 & 21.8 \\
\hline dimethenamid-P & $0.05^{*^{\mathrm{a}}}$ & 120 & $\begin{array}{l}10 \\
15 \\
\end{array}$ & $\begin{array}{l}276->244 \\
276->168\end{array}$ & 0.005-.08 & 0.993 & 0.005 & 92.9 & 7.6 & 0.0006 & 10.7 & 0.0009 & 17.4 \\
\hline epoxyconazole & $0.05^{\mathrm{a}}$ & 130 & $\begin{array}{l}25 \\
50\end{array}$ & $\begin{array}{l}330-121 \\
330->101\end{array}$ & $0.01-0.16$ & 0.992 & 0.01 & 95.2 & 7.8 & 0.0011 & 10.6 & 0.0019 & 18.0 \\
\hline
\end{tabular}




\begin{tabular}{|c|c|c|c|c|c|c|c|c|c|c|c|c|c|}
\hline Active substance & $\begin{array}{l}\mathrm{MRL}^{\mathrm{a}, \mathrm{b}} \\
\left(\mathrm{mg} \mathrm{kg}^{-1}\right)\end{array}$ & $\begin{array}{c}\mathrm{F} \\
(\mathrm{V})\end{array}$ & $\begin{array}{l}\mathrm{CE} \\
(\mathrm{V})\end{array}$ & $\begin{array}{c}\text { MRM } \\
\text { transitions }^{\mathrm{c}} \\
(\mathrm{m} / \mathrm{z})\end{array}$ & $\begin{array}{l}\text { Linearity } \\
\text { range } \\
\left(\mathrm{mg} \mathrm{kg}^{-1}\right)\end{array}$ & $\mathrm{R}^{2}$ & $\begin{array}{c}\text { LOQ } \\
\left(\mathrm{mg} \mathrm{kg}^{-1}\right)\end{array}$ & $\begin{array}{c}\text { Recovery } \\
(\%)\end{array}$ & $\begin{array}{l}\text { RSD } \\
(\%)\end{array}$ & $\begin{array}{l}\mathrm{U}_{\mathrm{r}} \text { (refer to } \\
\left(\mathrm{mg} \mathrm{kg}^{-1}\right) \\
\end{array}$ & \begin{tabular}{|c|}
$\mathrm{U}_{\mathrm{r}}$ (refer \\
to legend) \\
$(\%)$ \\
$(\%)$
\end{tabular} & $\begin{array}{c}\mathrm{U}_{\mathrm{R}} \text { (refer to } \\
\text { legend) } \\
\left(\mathrm{mg} \mathrm{kg}^{-1}\right) \\
\end{array}$ & $\begin{array}{c}\mathrm{U}_{\mathrm{R}}{ }^{\text {(refer }} \\
\text { to legend) } \\
(\%) \\
\end{array}$ \\
\hline ethofumesate & $0.05 *^{\mathrm{a}}$ & 130 & $\begin{array}{c}5 \\
15 \\
\end{array}$ & $\begin{array}{l}287-259 \\
287->121\end{array}$ & $0.005-0.08$ & 0.998 & 0.005 & 94.7 & 8.4 & 0.0006 & 10.7 & 0.0010 & 19.5 \\
\hline ethoprophos & l & 80 & $\begin{array}{l}15 \\
20 \\
\end{array}$ & $\begin{array}{c}243->131 \\
243->97\end{array}$ & $0.005-0.08$ & 0.996 & 0.005 & 93.8 & 9.1 & 0.0007 & 13.4 & 0.0011 & 20.9 \\
\hline famoxadone & $0.05^{*^{\mathrm{a}}}$ & 80 & $\begin{array}{l}10 \\
10 \\
\end{array}$ & $\begin{array}{l}392->331 \\
392->238\end{array}$ & $0.01-0.40$ & 0.997 & 0.01 & 95.1 & 9.5 & 0.0015 & 14.3 & 0.0092 & 21.8 \\
\hline fenazaquin & $0.01 *^{\mathrm{a}}$ & 120 & $\begin{array}{l}15 \\
20\end{array}$ & $\begin{array}{c}307-161 \\
307 \rightarrow 57\end{array}$ & 0.003-0.08 & 0.997 & 0.003 & 92.5 & 12.7 & 0.0004 & 13.3 & 0.0010 & 29.4 \\
\hline fenhexamid & $0.05^{* a}$ & 110 & $\begin{array}{l}25 \\
30\end{array}$ & $\begin{array}{l}302->97 \\
302->55\end{array}$ & $0.005-0.20$ & 0.995 & 0.005 & 93.4 & 9.5 & 0.0009 & 17.0 & 0.0012 & 21.7 \\
\hline fenoxycarb & $0.05 *^{\mathrm{a}}$ & 110 & $\begin{array}{c}5 \\
20 \\
\end{array}$ & $\begin{array}{c}302->116 \\
302->88\end{array}$ & $0.005-0.08$ & 0.992 & 0.005 & 93.0 & 8.2 & 0.0005 & 8.7 & 0.0010 & 19.0 \\
\hline fenpropidin & $0.05 *^{\mathrm{a}}$ & 155 & $\begin{array}{l}30 \\
60 \\
\end{array}$ & $\begin{array}{l}274-147 \\
274->117\end{array}$ & $0.005-0.08$ & 0.995 & 0.005 & 92.9 & 6.7 & 0.0005 & 8.4 & 0.0008 & 15.4 \\
\hline fenpyroximate & $0.05 *^{\mathrm{a}}$ & 130 & $\begin{array}{l}15 \\
40 \\
\end{array}$ & $\begin{array}{l}422->366 \\
422->165\end{array}$ & $0.005-0.08$ & 0.993 & 0.005 & 92.3 & 9.0 & 0.0006 & 11.4 & 0.0011 & 20.8 \\
\hline fipronil & $0.005^{*^{\mathrm{a}}}$ & 110 & $\begin{array}{l}10 \\
25\end{array}$ & $\begin{array}{l}435-330^{\mathrm{c}} \\
435-278^{\mathrm{c}}\end{array}$ & $0.005-0.20$ & 0.997 & 0.005 & 93.0 & 7.8 & 0.0005 & 9.3 & 0.0010 & 18.0 \\
\hline fluazifop butyl & $0.05^{* a}$ & 120 & $\begin{array}{l}15 \\
20 \\
\end{array}$ & $\begin{array}{l}384->328 \\
384->282\end{array}$ & $0.005-0.08$ & 0.991 & 0.005 & 95.3 & 8.3 & 0.0005 & 9.8 & 0.0009 & 19.3 \\
\hline fluazinam & $0.05^{*^{\mathrm{a}}}$ & 135 & $\begin{array}{l}15 \\
10 \\
\end{array}$ & $\begin{array}{l}463-416^{\mathrm{c}} \\
463-398^{\mathrm{c}}\end{array}$ & $0.005-0.08$ & 0.996 & 0.005 & 89.6 & 8.7 & 0.0006 & 11.2 & 0.0011 & 20.2 \\
\hline flufenoxuron & l & 80 & $\begin{array}{l}10 \\
15 \\
\end{array}$ & $\begin{array}{l}489-158 \\
489->141\end{array}$ & $0.005-0.20$ & 0.998 & 0.005 & 93.8 & 11.9 & 0.0004 & 9.1 & 0.0013 & 27.4 \\
\hline flusilazole & $0.05^{* a}$ & 120 & $\begin{array}{l}15 \\
30\end{array}$ & $\begin{array}{l}316 \rightarrow 247 \\
316->165\end{array}$ & $0.005-0.08$ & 0.994 & 0.005 & 94.1 & 10.8 & 0.0007 & 15.7 & 0.0012 & 24.9 \\
\hline flutriafol & $0.05^{*^{a}}$ & 100 & $\begin{array}{l}15 \\
15 \\
\end{array}$ & $\begin{array}{l}302->123 \\
302->109\end{array}$ & $0.01-0.40$ & 0.997 & 0.01 & 93.2 & 10.8 & 0.0012 & 13.1 & 0.0023 & 24.6 \\
\hline
\end{tabular}




\begin{tabular}{|c|c|c|c|c|c|c|c|c|c|c|c|c|c|}
\hline Active substance & $\begin{array}{l}\mathrm{MRL}^{\mathrm{a}, \mathrm{b}} \\
\left(\mathrm{mg} \mathrm{kg}^{-1}\right)\end{array}$ & $\begin{array}{c}\mathrm{F} \\
(\mathrm{V})\end{array}$ & $\begin{array}{l}\text { CE } \\
\text { (V) }\end{array}$ & $\begin{array}{c}\text { MRM } \\
\text { transitions }^{\mathrm{c}} \\
(\mathrm{m} / \mathrm{z})\end{array}$ & $\begin{array}{l}\text { Linearity } \\
\text { range } \\
\left(\mathrm{mg} \mathrm{kg}^{-1}\right)\end{array}$ & $\mathrm{R}^{2}$ & $\begin{array}{c}\text { LOQ } \\
\left(\mathrm{mg} \mathrm{kg}^{-1}\right)\end{array}$ & $\begin{array}{c}\text { Recovery } \\
(\%)\end{array}$ & $\begin{array}{c}\mathrm{RSD} \\
(\%)\end{array}$ & $\begin{array}{l}\mathrm{U}_{\mathrm{r}}^{\text {legend })} \\
\left(\mathrm{mg} \mathrm{kg}^{-1}\right)\end{array}$ & $\begin{array}{c}\mathrm{U}_{\mathrm{r}}^{(\text {refer }} \\
\text { to legend) } \\
(\%) \\
(\%)\end{array}$ & $\begin{array}{l}\mathrm{U}_{\mathrm{R}}^{\text {legend) }} \text { (refer to } \\
\left(\mathrm{mg} \mathrm{kg}^{-1}\right)\end{array}$ & $\begin{array}{c}\mathrm{U}_{\mathrm{R}} \text { (refer } \\
\text { to legend) } \\
(\%)\end{array}$ \\
\hline hexaconazole & I & 80 & $\begin{array}{l}10 \\
10\end{array}$ & $\begin{array}{c}314 \longrightarrow 159 \\
314-70\end{array}$ & $0.01-0.40$ & 0.998 & 0.01 & 93.1 & 10.6 & 0.0010 & 11.0 & 0.0023 & 24.4 \\
\hline hexythiazox & $0.02 *^{\mathrm{a}}$ & 120 & $\begin{array}{l}10 \\
20 \\
\end{array}$ & $\begin{array}{l}353->228 \\
353->168 \\
\end{array}$ & $0.005-0.20$ & 0.997 & 0.005 & 92.1 & 9.9 & 0.0006 & 12.4 & 0.0010 & 22.6 \\
\hline iprovalicarb & $0.05^{*^{\mathrm{a}}}$ & 95 & $\begin{array}{c}5 \\
20 \\
\end{array}$ & $\begin{array}{l}321->203 \\
321->119\end{array}$ & $0.005-0.08$ & 0.998 & 0.005 & 94.8 & 9.2 & 0.0003 & 12.0 & 0.0006 & 21.0 \\
\hline isoproturon & $0.05^{*^{\mathrm{a}}}$ & 100 & $\begin{array}{l}10 \\
25\end{array}$ & $\begin{array}{c}\stackrel{207-\longrightarrow}{ } 165 \\
207-72\end{array}$ & $0.01-0.16$ & 0.993 & 0.01 & 92.8 & 7.4 & 0.0007 & 7.8 & 0.0016 & 16.7 \\
\hline lufenuron & $0.05^{*^{\mathrm{a}}}$ & 120 & $\begin{array}{l}20 \\
50\end{array}$ & $\begin{array}{l}511 \rightarrow 158 \\
511 \rightarrow 141\end{array}$ & $0.005-0.20$ & 0.996 & 0.005 & 93.5 & 10.6 & 0.0006 & 11.9 & 0.0011 & 24.1 \\
\hline metazachlor & $0.05^{*^{\mathrm{a}}}$ & 100 & $\begin{array}{l}15 \\
15 \\
\end{array}$ & $\begin{array}{l}278->210 \\
278->134\end{array}$ & $0.01-0.16$ & 0.994 & 0.01 & 92.8 & 7.6 & 0.0009 & 10.1 & 0.0016 & 17.3 \\
\hline methoxyfenozide & $0.05^{*^{\mathrm{a}}}$ & 90 & $\begin{array}{c}0 \\
15\end{array}$ & $\begin{array}{l}369-313 \\
369-149\end{array}$ & $0.005-0.08$ & 0.991 & 0.005 & 93.8 & 7.9 & 0.0004 & 8.6 & 0.0009 & 18.5 \\
\hline metosulam & $0.05^{*^{\mathrm{a}}}$ & 160 & $\begin{array}{l}20 \\
40\end{array}$ & $\begin{array}{l}418-175 \\
418->140\end{array}$ & $0.005-0.20$ & 0.996 & 0.005 & 91.8 & 11.0 & 0.0005 & 10.8 & 0.0012 & 25.2 \\
\hline monocrotophos & l & 100 & $\begin{array}{c}0 \\
10 \\
\end{array}$ & $\begin{array}{l}224->193 \\
224->127\end{array}$ & $0.005-0.08$ & 0.994 & 0.005 & 93.3 & 7.9 & 0.0004 & 8.8 & 0.0009 & 18.7 \\
\hline napropamide & / & 120 & $\begin{array}{l}15 \\
15\end{array}$ & $\begin{array}{l}272->171 \\
272->129\end{array}$ & $0.005-0.08$ & 0.994 & 0.005 & 93.4 & 9.0 & 0.0006 & 12.5 & 0.0010 & 20.4 \\
\hline pendimethalin & $0.05^{*^{\mathrm{a}}}$ & 80 & $\begin{array}{c}5 \\
10 \\
\end{array}$ & $\begin{array}{l}282 \rightarrow 212 \\
282 \rightarrow 194\end{array}$ & $0.010-0.40$ & 0.996 & 0.01 & 93.3 & 9.0 & 0.0011 & 11.6 & 0.0019 & 20.8 \\
\hline phenmedipham & $0.05^{*^{\mathrm{a}}}$ & 80 & $\begin{array}{l}15 \\
20 \\
\end{array}$ & $\begin{array}{l}301 \rightarrow 168 \\
301 \rightarrow 138 \\
\end{array}$ & $0.01-0.08$ & 0.996 & 0.01 & 93.5 & 7.5 & 0.0009 & 8.6 & 0.0019 & 17.3 \\
\hline phorate sulfon & $0.01 *^{\mathrm{a}}$ & 70 & $\begin{array}{c}0 \\
20\end{array}$ & $\begin{array}{l}293 \rightarrow 171 \\
293->115\end{array}$ & $0.005-0.04$ & 0.993 & 0.005 & 94.6 & 11.0 & 0.0006 & 11.8 & 0.0012 & 25.2 \\
\hline phoxim & $0.02 *^{\mathrm{a}}$ & 80 & $\begin{array}{l}15 \\
15 \\
\end{array}$ & $\begin{array}{c}299-129 \\
299->77\end{array}$ & $0.005-0.08$ & 0.995 & 0.005 & 91.6 & 9.8 & 0.0005 & 11.5 & 0.0010 & 22.5 \\
\hline
\end{tabular}




\begin{tabular}{|c|c|c|c|c|c|c|c|c|c|c|c|c|c|}
\hline Active substance & $\begin{array}{l}\mathrm{MRL}^{\mathrm{a}, \mathrm{b}} \\
\left(\mathrm{mg} \mathrm{kg}^{-1}\right)\end{array}$ & $\begin{array}{c}\mathrm{F} \\
(\mathrm{V})\end{array}$ & $\begin{array}{l}\text { CE } \\
\text { (V) }\end{array}$ & $\begin{array}{c}\text { MRM } \\
\text { transitions }^{\mathrm{c}} \\
(\mathrm{m} / \mathrm{z})\end{array}$ & $\begin{array}{l}\text { Linearity } \\
\text { range } \\
\left(\mathrm{mg} \mathrm{kg}^{-1}\right)\end{array}$ & $\mathrm{R}^{2}$ & $\begin{array}{c}\text { LOQ } \\
\left(\mathrm{mg} \mathrm{kg}^{-1}\right)\end{array}$ & $\begin{array}{c}\text { Recovery } \\
(\%)\end{array}$ & $\begin{array}{c}\mathrm{RSD} \\
(\%)\end{array}$ & $\begin{array}{c}\begin{array}{c}\mathrm{r} \\
\text { legend })\end{array} \\
\left(\mathrm{mg} \mathrm{kg}^{-1}\right)\end{array}$ & $\begin{array}{c}\mathrm{U}_{\mathrm{r}}^{(\text {refer }} \\
\text { to legend) } \\
(\%) \\
(\%)\end{array}$ & $\begin{array}{l}\mathrm{U}_{\mathrm{R}}^{\text {legend) }} \text { (refer to } \\
\left(\mathrm{mg} \mathrm{kg}^{-1}\right)\end{array}$ & $\begin{array}{c}\mathrm{U}_{\mathrm{R}} \text { (refer } \\
\text { to legend) } \\
(\%)\end{array}$ \\
\hline pyraflufen-ethyl & $0.05 *^{\mathrm{a}}$ & 120 & $\begin{array}{l}20 \\
30\end{array}$ & $\begin{array}{l}413 \longrightarrow 339 \\
413-289\end{array}$ & $0.01-0.40$ & 0.999 & 0.01 & 93.6 & 9.4 & 0.0012 & 12.5 & 0.0020 & 21.7 \\
\hline prochloraz & / & 90 & $\begin{array}{l}90 \\
15 \\
\end{array}$ & $\begin{array}{l}376-308 \\
376->266\end{array}$ & $0.005-0.04$ & 0.991 & 0.005 & 93.5 & 9.8 & 0.0003 & 7.2 & 0.0011 & 22.8 \\
\hline propaquizafop & $0.05^{*^{\mathrm{a}}}$ & 60 & $\begin{array}{l}20 \\
15 \\
\end{array}$ & $\begin{array}{l}444->299 \\
444->100\end{array}$ & $0.005-0.20$ & 0.997 & 0.005 & 92.5 & 10.3 & 0.0004 & 8.1 & 0.0011 & 23.4 \\
\hline propiconazole & $0.05^{*^{\mathrm{a}}}$ & 140 & $\begin{array}{l}25 \\
25\end{array}$ & $\begin{array}{c}342 \longrightarrow 159 \\
342 \longrightarrow 69\end{array}$ & $0.005-0.20$ & 0.996 & 0.005 & 91.2 & 9.5 & 0.0007 & 15.3 & 0.0010 & 21.8 \\
\hline pyraclostrobin & $0.05^{*^{\mathrm{a}}}$ & 110 & $\begin{array}{c}5 \\
25\end{array}$ & $\begin{array}{l}388->194 \\
388->163\end{array}$ & $0.005-0.08$ & 0.995 & 0.005 & 92.7 & 8.7 & 0.0005 & 10.1 & 0.0009 & 20.0 \\
\hline pyrazophos & $0.05^{*^{\mathrm{a}}}$ & 125 & $\begin{array}{l}15 \\
50\end{array}$ & $\begin{array}{c}374-222 \\
374 \rightarrow 70\end{array}$ & $0.01-0.40$ & 0.997 & 0.01 & 93.2 & 10.0 & 0.0013 & 13.7 & 0.0022 & 23.4 \\
\hline pyridaben & $0.02 *^{\mathrm{a}}$ & 100 & $\begin{array}{l}10 \\
30\end{array}$ & $\begin{array}{l}365-309 \\
365->147\end{array}$ & $0.005-0.08$ & 0.994 & 0.005 & 94.7 & 8.9 & 0.0004 & 7.8 & 0.0010 & 20.6 \\
\hline pyriproxyfen & $0.05^{*^{\mathrm{a}}}$ & 100 & $\begin{array}{l}30 \\
20\end{array}$ & $\begin{array}{c}322-185 \\
322->96\end{array}$ & $0.005-0.04$ & 0.992 & 0.005 & 93.9 & 9.0 & 0.0004 & 9.3 & 0.0010 & 20.7 \\
\hline spinosyn A & $0.05^{*^{\mathrm{a}}}$ & 140 & $\begin{array}{l}35 \\
35 \\
\end{array}$ & $\begin{array}{l}732,5 \rightarrow 142 \\
732,5 \rightarrow 98\end{array}$ & $0.005-0.16$ & 0.996 & 0.005 & 93.3 & 7.8 & 0.0004 & 9.2 & 0.0008 & 18.1 \\
\hline spinosyn D & $0.05^{*^{\mathrm{a}}}$ & 100 & $\begin{array}{l}15 \\
15 \\
\end{array}$ & $\begin{array}{c}746,5 \rightarrow 142 \\
746,5 \rightarrow 98\end{array}$ & $0.005-0.40$ & 0.999 & 0.005 & 93.0 & 13.1 & 0.0008 & 18.0 & 0.0014 & 29.8 \\
\hline spirodiclofen & $0.05^{*^{\mathrm{a}}}$ & 110 & $\begin{array}{c}5 \\
15\end{array}$ & $\begin{array}{c}411 \rightarrow 313 \\
411 \rightarrow 71\end{array}$ & $0.005-0.08$ & 0.993 & 0.005 & 92.2 & 7.5 & 0.0005 & 10.0 & 0.0008 & 17.3 \\
\hline tebufenozide & $0.05^{* a}$ & 90 & $\begin{array}{c}0 \\
15 \\
\end{array}$ & $\begin{array}{l}353->297 \\
353->133\end{array}$ & $0.005-0.08$ & 0.992 & 0.005 & 92.8 & 7.6 & 0.0004 & 8.5 & 0.0008 & 17.7 \\
\hline terbuthylazine & l & 120 & $\begin{array}{l}15 \\
40 \\
\end{array}$ & $\begin{array}{c}230-174 \\
230->68\end{array}$ & $0.005-0.08$ & 0.998 & 0.005 & 93.1 & 6.4 & 0.0004 & 9.1 & 0.0007 & 14.7 \\
\hline thiacloprid & $0.2^{\mathrm{a}}$ & 90 & $\begin{array}{l}10 \\
20\end{array}$ & $\begin{array}{l}253 \rightarrow 186 \\
253 \rightarrow 126\end{array}$ & $0.005-0.08$ & 0.995 & 0.005 & 92.1 & 7.5 & 0.0003 & 6.2 & 0.0008 & 17.1 \\
\hline
\end{tabular}




\begin{tabular}{|c|c|c|c|c|c|c|c|c|c|c|c|c|c|}
\hline Active substance & $\begin{array}{l}\mathrm{MRL}^{\mathrm{a}, \mathrm{b}} \\
\left(\mathrm{mg} \mathrm{kg}^{-1}\right)\end{array}$ & $\begin{array}{c}\mathrm{F} \\
(\mathrm{V})\end{array}$ & $\begin{array}{l}\text { CE } \\
\text { (V) }\end{array}$ & $\begin{array}{c}\text { MRM } \\
\text { transitions }^{\mathrm{c}} \\
(\mathrm{m} / \mathrm{z})\end{array}$ & $\begin{array}{l}\text { Linearity } \\
\text { range } \\
\left(\mathrm{mg} \mathrm{kg}^{-1}\right)\end{array}$ & $\mathrm{R}^{2}$ & $\begin{array}{c}\text { LOQ } \\
\left(\mathrm{mg} \mathrm{kg}^{-1}\right)\end{array}$ & $\begin{array}{c}\text { Recovery } \\
(\%)\end{array}$ & $\begin{array}{c}\mathrm{RSD} \\
(\%)\end{array}$ & $\begin{array}{l}\mathrm{U}_{\mathrm{r}}^{\text {legend }} \text { (refer to } \\
\left(\mathrm{mg} \mathrm{kg}^{-1}\right)\end{array}$ & $\begin{array}{c}\mathrm{U}_{\mathrm{r}} \text { (refer } \\
\text { to legend) } \\
(\%)\end{array}$ & $\begin{array}{l}\mathrm{U}_{\mathrm{R}} \text { (refer to } \\
\left(\mathrm{mg} \mathrm{kg}^{-1}\right)\end{array}$ & $\begin{array}{c}\mathrm{U}_{\mathrm{R}} \text { (refer } \\
\text { to legend) } \\
(\%)\end{array}$ \\
\hline thiamethoxam & $0.05^{*^{\mathrm{a}}}$ & 90 & $\begin{array}{l}10 \\
20\end{array}$ & $\begin{array}{l}292 \longrightarrow 211 \\
292 \longrightarrow 181\end{array}$ & $0.005-0.08$ & 0.992 & 0.005 & 91.0 & 7.7 & 0.0004 & 9.7 & 0.0008 & 17.8 \\
\hline thiodicarb & $0.05^{* a}$ & 90 & $\begin{array}{l}10 \\
15\end{array}$ & $\begin{array}{c}355-108 \\
355 \rightarrow 88\end{array}$ & $0.005-0.08$ & 0.994 & 0.005 & 92.0 & 8.3 & 0.0004 & 8.9 & 0.0009 & 19.3 \\
\hline triasulfuron & $0.05^{*^{\mathrm{a}}}$ & 140 & $\begin{array}{l}10 \\
15 \\
\end{array}$ & $\begin{array}{l}402->167 \\
402->141\end{array}$ & $0.005-0.40$ & 0.997 & 0.005 & 91.7 & 9.1 & 0.0005 & 11.8 & 0.0010 & 20.7 \\
\hline trichlorfon & $0.01^{*^{\mathrm{a}}}$ & 105 & $\begin{array}{l}10 \\
10 \\
\end{array}$ & $\begin{array}{l}402-141 \\
402->141 \\
\end{array}$ & $0.01-0.16$ & 0.993 & 0.01 & 92.1 & 6.5 & 0.0012 & 13.5 & 0.0014 & 15.1 \\
\hline trinexapac-ethyl & $0.05^{*^{\mathrm{a}}}$ & 95 & $\begin{array}{c}0 \\
20\end{array}$ & $\begin{array}{l}257 \rightarrow 221 \\
257 \rightarrow 127\end{array}$ & $0.01-0.16$ & 0.994 & 0.01 & 93.9 & 8.3 & 0.0010 & 10.3 & 0.0018 & 19.3 \\
\hline
\end{tabular}

${ }^{a}$ Regulation (EC) 396/2005

${ }^{\mathrm{b}}$ Regulation (EC) 37/2010

*means that MRL is set in Regulation (EC) 396/2005 at LOQ of analytical method of different laboratories

${ }^{\mathrm{c}}$ means in negative Electro Spray Ionisation mode

RSD was obtained during recovery analyses

$\mathrm{U}_{\mathrm{r}}$ is uncertainty of repeatability

$U_{R}$ is uncertainty of reproducibility 
Table 4: Linear response for GC/MS and LC-MS/MS determination

\begin{tabular}{|c|c|c|}
\hline Determination with & $\begin{array}{l}\text { Linear response in range } \\
\left(\mathrm{mg} \mathrm{kg}^{-1}\right)\end{array}$ & No. of active substances giving linear response \\
\hline GC/MS & $0.01-0.15$ & 16 \\
\hline GC/MS & $0.02-0.1$ & 1 \\
\hline GC/MS & $0.02-0.15$ & 5 \\
\hline GC/MS & $0.03-0.15$ & 3 \\
\hline GC/MS & $0.05-0.1$ & 1 \\
\hline GC/MS & $0.05-0.15$ & 47 \\
\hline GC/MS & $0.05-0.2$ & 2 \\
\hline LC-MS/MS & $0.003-0.008$ & 1 \\
\hline LC-MS/MS & $0.005-0.04$ & 3 \\
\hline LC-MS/MS & $0.005-0.08$ & 28 \\
\hline LC-MS/MS & $0.005-0.16$ & 2 \\
\hline LC-MS/MS & $0.005-0.2$ & 11 \\
\hline LC-MS/MS & $0.005-0.4$ & 2 \\
\hline LC-MS/MS & $0.01-0.08$ & 2 \\
\hline LC-MS/MS & $0.01-0.16$ & 5 \\
\hline LC-MS/MS & $0.01-0.4$ & 6 \\
\hline
\end{tabular}


Table 5: Pesticide residues in honey samples in 2017 and 2018

\begin{tabular}{|l|c|c|c|c|}
\hline & amitraz & coumaphos & thiacloprid & thymol \\
\hline MRL $\left(\mathrm{mg} \mathrm{kg}^{-1}\right)$ & $0.2(\mathrm{a})$ & $0.1(\mathrm{a})$ & $0.2(\mathrm{~b})$ & $/$ \\
\hline \multicolumn{5}{|c|}{ conventional production } \\
\hline Min content $\left(\mathrm{mg} \mathrm{kg}^{-1}\right)$ & 0.01 & 0.009 & $<0.005$ & 0.08 \\
\hline Max content $\left(\mathrm{mg} \mathrm{kg}^{-1}\right)$ & 0.12 & 0.055 & $<0.005$ & 0.22 \\
\hline Average $\left(\mathrm{mg} \mathrm{kg}^{-1}\right)$ & 0.04 & 0.023 & n.a. & 0.13 \\
\hline SD $\left(\mathrm{mg} \mathrm{kg}^{-1}\right)$ & 0.03 & 0.015 & n.a. & 0.07 \\
\hline $\begin{array}{l}\text { No. of samples where } \\
\text { residues were found }\end{array}$ & 14 & 13 & 0 & 3 \\
\hline \multicolumn{5}{|c|}{ organic production } \\
\hline Min content (mg kg-1) & 0.01 & $<0.009$ & 0.018 & 0.43 \\
\hline Max content (mg kg & & \\
\hline Average $\left(\mathrm{mg} \mathrm{kg}^{-1}\right)$ & 0.01 & $<0.009$ & 0.018 & 0.43 \\
\hline SD (mg kg & 0.1 & n.a. & n.a. & n.a. \\
\hline $\begin{array}{l}\text { No. of samples where } \\
\text { residues were found }\end{array}$ & 0.00 & n.a. & n.a. & n.a. \\
\hline
\end{tabular}

n.a. means not applicable
(a) Regulation (EC) $37 / 2010$
(b) Regulation (EC) 396/2005 


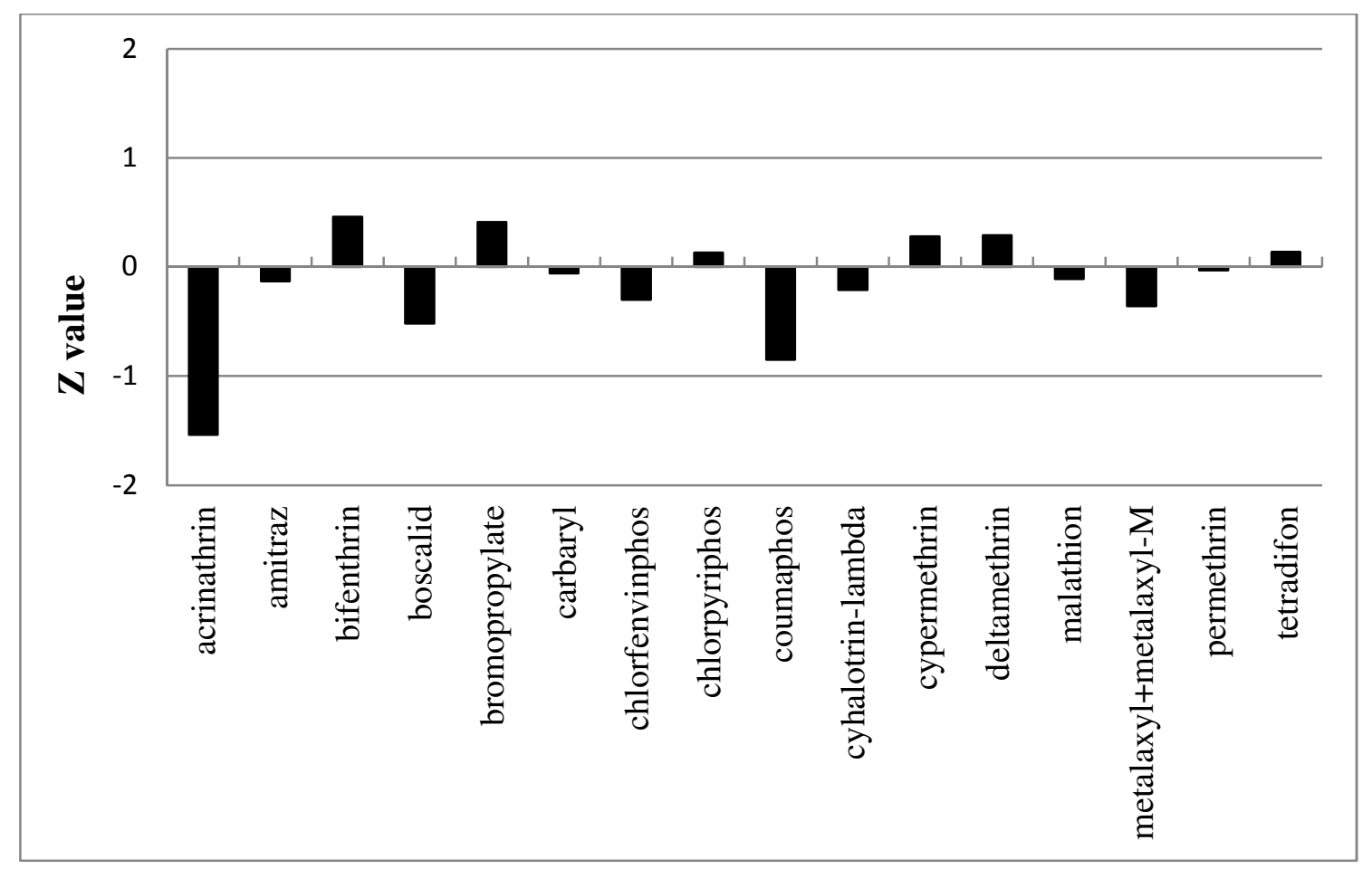

Figure 1: BIPEA interlaboratory comparisons (BIPEA 2017a and 2017b)

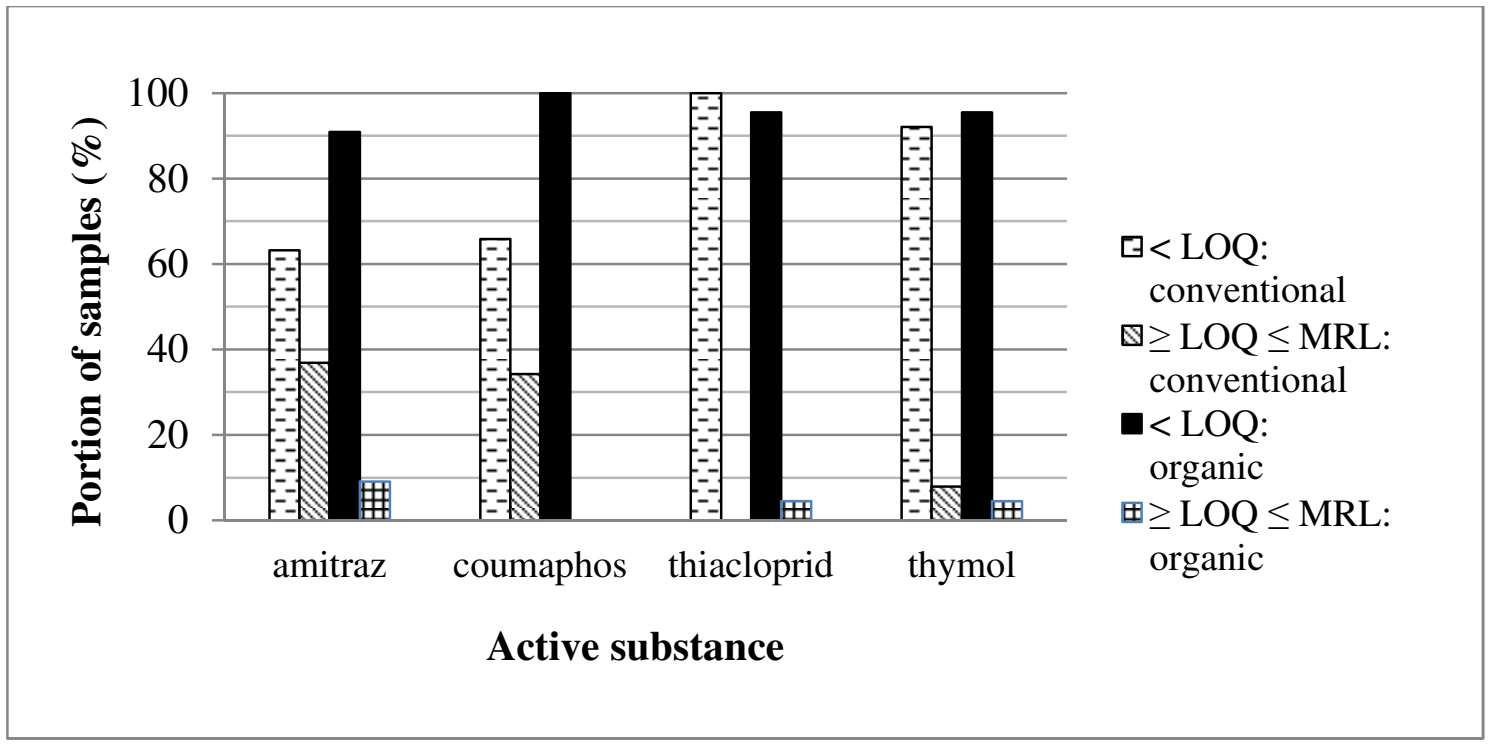

Figure 2: Portion of samples for conventional and organic production in 2017 and 2018 